\title{
The New World of Agency Adjudication
}

\author{
Christopher J. Walker* \& Melissa F. Wasserman ${ }^{* *}$
}

In 1946, the Administrative Procedure Act (APA) set forth the criteria for "formal" adjudication, requiring an administrative law judge to make the initial determination and the agency head to have the final word. That is the lost world. Today, the vast majority of agency adjudications Congress has created are not paradigmatic "formal" adjudications as set forth in the APA. It turns out that there is great diversity in the procedures by which federal agencies adjudicate. This new world involves a variety of less-independent administrative judges, hearing officers, and other agency personnel adjudicating disputes. But, like in the lost world, the agency head retains final decision-making authority.

In 2011, Congress created yet another novel agency tribunalthe Patent Trial and Appeal Board (PTAB)—to adjudicate patent validity disputes between private parties. Questions abound concerning the PTAB's proper place in the modern administrative state, as its features depart from the textbook accounts of APAgoverned "formal" adjudication. Many of these questions are working

DOI: https://doi.org/10.15779/Z38Q23R09S

Copyright (C) 2019 California Law Review, Inc. California Law Review, Inc. (CLR) is a California nonprofit corporation. CLR and the authors are solely responsible for the content of their publications.

* Associate Professor of Law, The Ohio State University Moritz College of Law.

** Charles Tilford McCormick Professor of Law, The University of Texas at Austin School of Law. The authors would like to thank David Adelman, Michael Asimow, Kent Barnett, Lynn Blais, Emily Bremer, Michael Burstein, Michael Frakes, John Golden, Paul Gugliuzza, Kristin Hickman, Dmitry Karshtedt, Mark Lemley, Ronald Levin, Tom McGarity, Arti Rai, Greg Reilly, Guy Rub, Michael Sant'Ambrogio, Wendy Wagner, Adam Zimmerman, and the participants at SEALS 2017 Conference, the Power of PTAB Conference, Perspectives on the PTAB Conference, the 33rd Annual Federal Circuit Symposium, the American Bar Association 2017 Annual Administrative Law Conference, 18th Annual Intellectual Property Scholars Conference, and the Northwestern University Law Faculty Workshop. The authors received funding from George Mason University's Center for the Study of the Administrative State to prepare and present this Article at the New Role of the Administrative State in the Innovation Economy Conference. 
their way through the Federal Circuit and to the Supreme Court. Indeed, the Supreme Court recently held in Oil States Energy Services that PTAB adjudication does not unconstitutionally strip parties of their property rights in issued patents - while expressly leaving open many questions concerning the limits of administrative adjudication.

This Article situates PTAB adjudication within administrative law's larger landscape of agency adjudication. By surveying this new world of agency adjudication, we find that PTAB adjudication is not extraordinary. But we also identify one core feature of modern agency adjudication that is absent at the PTAB: the Director of the Patent and Trademark Office lacks final decision-making authority. To be sure, the Director has some power to influence outcomes: in the past, she has ordered rehearing of cases and stacked the board with administrative patent judges who share her substantive vision. But these second-best means of agency-head control raise problems of their own, including constitutional questions and inefficiencies in agency performance. This Article concludes by exploring alternative mechanisms that would remedy the lack of agency-head review at the PTAB.

Introduction 143

I. Understanding Modern Agency Adjudication. 148

A. The Lost World: APA-Governed Adjudication..................... 148

B. The New World: Adjudication Outside of the APA............. 153

II. The PTAB Revolution.

III. Situating PTAB Adjudication Within the New World of Agency

Adjudication 162

A. PTAB Adjudication, the APA, and the Lost World .............162

B. PTAB Adjudication Within the New World ...........................165

C. PTAB Adjudication Beyond the New World ........................ 168

IV. The Importance of Agency-Head Final Decision-Making Authority

A. Ramifications of the Lack of Agency-Head Final DecisionMaking Authority 175

B. The Director's Authority to "Stack" PTAB Panels 178

C. Alternative Mechanisms for Increased Agency-Head Control of PTAB Adjudication. 188 


\section{INTRODUCTION}

Every administrative law student learns the basics of "formal" agency adjudication under the Administrative Procedure Act (APA). Paradigmatic APA formal adjudication involves an evidentiary hearing held before an administrative law judge (ALJ) where parties are entitled to oral arguments, rebuttal, and cross-examination of witnesses. ${ }^{1}$ ALJs presiding over formal adjudicatory hearings are functionally equivalent to a trial judge in a bench trial. ${ }^{2}$ The critical difference from the judicial model is that the agency head reviews ALJ decisions de novo and has final decision-making authority. ${ }^{3}$

The vast majority of agency adjudications today, however, do not look like APA formal adjudication. Instead, agencies regulate using adjudicatory means that still require evidentiary hearings but do not embrace all of the features set forth in the APA. To borrow from Daniel Farber and Anne O'Connell, the predominance of formal-like agency adjudication outside of the APA is yet another departure from the "lost world of administrative law"-further revealing "an increasing mismatch between the suppositions of modern administrative law and the realities of modern regulation." 4

This new world of formal adjudication outside of the APA is procedurally and substantively diverse. ${ }^{5}$ It covers a broad range of subject matters such as public benefits, disputes between federal agencies and private parties, and even disputes between private parties. Some new-world adjudicatory systems handle hundreds of thousands of cases a year, while others handle just a few cases annually. Many are essentially just as formal as APA-governed formal adjudication; others are quite informal. As the Administrative Conference of the United States observed, "Some proceedings are highly adversarial; others are inquisitorial. Caseloads vary. Some have huge backlogs and long delays; others seem relatively current. The structures for internal appeal also vary." 6

Despite this great diversity in adjudication across the modern administrative state, the "standard federal model" continues to vest final

1. See 1 Richard J. PierCe, Administrative LaW TREATiSe 703 (5th ed. 2010) (discussing formal adjudication procedures set forth in 5 U.S.C. $\S \S 554-557$ (2012)).

2. Id. See generally Thomas W. Merrill, Article III, Agency Adjudication, and the Origins of the Appellate Review Model of Administrative Law, 111 COLUM. L. REV. 939, 940 (2011) (detailing how "[m]odern administrative law is built on the appellate review model of the relationship between reviewing courts and agencies," which "borrow[s] from the understandings that govern the relationship between appeals courts and trial courts in civil litigation").

3. 5 U.S.C. § 557(b) (2012); accord FCC v. Allentown Broad. Corp., 349 U.S. 358, 364-65 (1955).

4. Daniel A. Farber \& Anne Joseph O'Connell, The Lost World of Administrative Law, 92 TEX. L. REV. 1137, 1140 (2014).

5. See infra Part I.B.

6. Adoption of Recommendations of the Admin. Conf. of the U.S., 81 Fed. Reg. 94, 312, 315 (Dec. 23, 2016). 
decision-making authority in the agency head. ${ }^{7}$ This feature has deep roots in the federal courts theory. Hart \& Weschler's distinguishes Article III courts and Article I legislative courts from agency tribunals in part because the agency head has final policy-making authority. ${ }^{8}$ Administrative law scholars, moreover, have long recognized and often criticized how federal agencies have the authority to make policy either through rulemaking or adjudication. ${ }^{9}$ That is, agency heads have almost unfettered authority to review and reverse their adjudicatory boards, through which they set binding policies for the agency.

Beyond enabling agency heads to control policy, agency-head review also empowers agency leadership to bring greater consistency to adjudicatory outcomes while concomitantly providing agency heads with a better understanding of how the regulatory system is functioning. Given these benefits, it is not too surprising that even though the new world is more diverse than the lost world, final decision-making authority in the agency head remains a touchstone of agency adjudication.

In 2011, Congress created yet another form of federal agency adjudication: certain proceedings conducted at the Patent Trial and Appeal Board (PTAB) of the Patent and Trademark Office (Patent Office).${ }^{10}$ At the time of its enactment, the Patent Office Director proclaimed that the Leahy-Smith America Invents Act (AIA) constituted "the most significant overhaul to our patent system, since the founding fathers first conceived of codifying a grand bargain between society and invention." 11 As part of this comprehensive reform, the AIA created the PTAB and established three new, fast-track administrative procedures for private parties to challenge issued patents before the PTAB.

The PTAB has transformed the relationship between Article III patent litigation and the administrative state. As of September 2018, the PTAB had received nearly 8,500 petitions challenging patents under these three AIA procedures. ${ }^{12}$ To adjudicate these claims, the Patent Office tripled its workforce of administrative patent judges (APJs), who generally adjudicate on three-judge

7. Ronald M. Levin, Administrative Judges and Agency Policy Development: The Koch Way, 22 WM. \& MARY BILL RTS. J. 407, 412 (2013).

8. RichaRD H. FALLON, JR., ET AL., HART \& WESCHLER'S THE FEDERAL COURTS AND THE FEDERAL SYSTEM 379-80 (7th ed. 2015); accord Richard H. Fallon, Jr., Of Legislative Courts, Administrative Agencies, and Article III, 101 HARV. L. REV. 915, 923-24 (1988).

9. See, e.g., M. Elizabeth Magill, Agency Choice of Policymaking Form, 71 U. CHI. L. REV. 1383, 1396-97 (2004); David L. Shapiro, The Choice of Rulemaking or Adjudication in the Development of Administrative Policy, 78 HARV. L. REV. 921, 922 (1965).

10. Leahy-Smith America Invents Act, Pub. L. No. 112-29, 125 Stat. 284 (2011) (codified in scattered sections of 35 U.S.C.).

11. David Kappos, Re-Inventing the US Patent System, USPTO: DiRECTOR's FORUM (Sept. 16, 2011), http://www.uspto.gov/blog/director/entry/re_inventing_the_us_patent [https://perma.cc/S8CRUZDC].

12. U.S. Patent \& TRAdemark Office, Trial Statistics: IPR, PGR, CBM (Sept. 2018), https://www.uspto.gov/sites/default/files/documents/trial_statistics_20180930a.pdf [https://perma.cc/QG2X-KPC7]. 
panels. ${ }^{13}$ In 2016, the US Court of Appeals for the Federal Circuit (Federal Circuit), which has near-exclusive jurisdiction over patent appeals, ${ }^{14}$ docketed more patent appeals arising from the PTAB than from the federal district courts. ${ }^{15}$

These new PTAB adjudications have raised numerous questions about administrative law and regulatory practice, which are working their way through the Federal Circuit and to the Supreme Court. Indeed, last Term in Oil States Energy Services v. Greene's Energy Group, the Supreme Court held that patent grants involve public rights and adjudicating patents without a jury at the PTAB - a non-Article III forum - is constitutionally permissible. ${ }^{16}$ At oral argument, the Court expressed concerns about a number of the new agency adjudication's features. For instance, Chief Justice Roberts and Justice Ginsburg both questioned whether the Patent Office Director's authority to change the agency adjudicators in the middle of PTAB proceedings offends due process. ${ }^{17}$ Justice Thomas, writing for the Oil States majority, expressly noted that the petitioner did not raise a due process challenge and thus the Court would save that question for another day. ${ }^{18}$

Some patent scholars have questioned the PTAB's legitimacy in the modern administrative state, suggesting perhaps that it is a new platypus of administrative law. ${ }^{19}$ After all, its procedures differ in significant ways from the

\footnotetext{
13. Kent Barnett et Al., Non-AlJ Adjudicators in Federal Agencies: Status, $\begin{array}{llllll}\text { SELECTION, } & \text { OVERSIGHT, } & \text { AND } & \text { REMOVAL } & 18 & \text { (2018), }\end{array}$ https:/www.acus.gov/sites/default/files/documents/Non-ALJ Draft Report_2.pdf [https://perma.cc/MHE2-UPYA] (reporting there were 275 administrative patent judges as of 2017).

14. See 28 U.S.C. $\S 1338$ (a) (2012) (granting district courts "original jurisdiction of any civil action arising under any Act of Congress relating to patents"); id. § 1295(a)(1) (granting the Federal Circuit "exclusive jurisdiction" over "an appeal from a final decision of a district court. . . in any civil action arising under ... any Act of Congress relating to patents"); id. § 1295(a)(4)(A) (granting the Federal Circuit "exclusive jurisdiction" over an appeal from a decision of "the Patent Trial and Appeal Board").

15. Jason Rantanen, The Federal Circuit and Appeals from the Patent Office, PATENTLYO (Dec. 4, 2016), https://patentlyo.com/patent/2016/12/federal-circuit-appeals.html [https://perma.cc/S29V4SY2].

16. Oil States Energy Servs., LLC v. Greene's Energy Grp., LLC, 138 S. Ct. 1365, 1375, 1379 (2018). Justice Thomas, writing for the Court, emphasized that the Court's holding was narrow. See id. at 1379 ("[W]e address only the precise constitutional challenges that Oil States raised here. Oil States does not challenge the retroactive application of inter partes review, even though that procedure was not in place when its patent issued. Nor has Oil States raised a due process challenge. Finally, our decision should not be misconstrued as suggesting that patents are not property for purposes of the Due Process Clause or the Takings Clause.”). Justice Gorsuch, joined by Chief Justice Roberts, dissented, arguing that PTAB adjudication unconstitutionally extinguishes private property rights through a non-Article III forum. Id. at 1385-86 (Gorsuch, J., dissenting).

17. Transcript of Oral Argument at 45, 64-65, Oil States Energy Servs., LLC v. Greene's Energy Grp., 138 S. Ct. 1365 (2018) (No. 16-712).

18. Oil States, 138 S. Ct. at 1379.

19. Cf. Kent Barnett, Looking More Closely at the Platypus of Formal Rulemaking, REG. REV. (May 11, 2017), https://www.theregreview.org/2017/05/11/barnett-platypus-formal-rulemaking [https://perma.cc/F8SR-YDHS] (referring to formal, on-the-record rulemaking as an old platypus in administrative law).
} 
formal adjudication procedures in the APA. In PTAB proceedings, APJs preside over the adjudication instead of ALJs, and the Patent Office Director does not have final decision-making authority over PTAB decisions.

In this Article, we situate the PTAB adjudicatory process within administrative law's larger movement away from the lost world of APA formal adjudication and toward the new world of quasi-formal adjudication that falls outside of the APA. As we demonstrate by detailing similar new world agency adjudications in a number of regulatory contexts, the PTAB's adjudicatory proceedings are not that unusual. Indeed, as we detail in Part III.B, PTAB adjudication embraces most of the best practices that administrative law experts have identified to ensure that these formal-like adjudications are procedurally fair and substantively consistent and accurate.

But PTAB adjudication also departs from both the lost world and the new world of agency adjudication in one critical respect: in the AIA, Congress did not grant the Patent Office Director final decision-making authority over PTAB adjudications. The Director does have some authority to have the final word: in the past, the Director has ordered rehearing of cases and stacked the PTAB with APJs who are sympathetic to the Director's views. But, these second-best means of agency-head control arguably raise problems of their own, most notably those of procedural fairness and due process that may be unconstitutional. In light of these concerns, in Part IV we explore alternative mechanisms - internal agency practices, agency rulemaking, or even statutory amendment - that would help remedy the Director's lack of final decision-making authority.

Situating the PTAB within the modern administrative state is critical for a number of reasons. First, the category of adjudication influences the judicial deference afforded to the agency's legal and factual determinations, as well as the procedural safeguards required. ${ }^{20}$ The Federal Circuit has repeatedly suggested that the PTAB proceedings are APA-governed formal adjudication and hence has imposed the APA's formal adjudication procedures on the Patent Office. ${ }^{21}$ This is incorrect. As we argue in Part III.A, the PTAB proceedings are not governed by the APA's formal adjudication requirements, even though they share many hallmarks of formal adjudication. Regardless of the merits of requiring the PTAB to implement the same procedural safeguards afforded to formal adjudication, it appears that the APA, contrary to the suggestion of the Federal Circuit, does not mandate these protections.

20. See infra Part I. See also Melissa F. Wasserman, The Changing Guard of Patent Law: Chevron Deference for the PTO, 54 WM. \& MARY L. REV. 1959, 1969-70 (2013).

21. See, e.g., Novartis AG v. Torrent Pharms. Ltd., 853 F.3d 1316, 1324 (Fed. Cir. 2017) ("In a formal adjudication ... the APA imposes certain procedural requirements on the agency."); accord Dell Inc. v. Acceleron, LLC, 818 F.3d 1293, 1301 (Fed. Cir. 2016); In re NuVasive, Inc., 841 F.3d 966, 971 (Fed. Cir. 2016). Notably, the Federal Circuit has not afforded PTAB's legal interpretations of ambiguous terms in the Patent Act any deference, which is highly unusual from an administrative law perspective. See Wasserman, supra note 20, at 1975. 
Second, understanding the extent to which PTAB features exist in other agency adjudications informs the debate regarding whether certain features of the Patent Office's new adjudicatory powers violate the APA or the Constitution. Because the field of patent law has historically lacked a robust engagement with administrative law theory and doctrine, a sustained comparison of PTAB adjudications with other agency adjudications can help focus challenges to PTAB features that are in fact unique and therefore more likely to be illegal. ${ }^{22}$ At a minimum, courts should better understand how invalidating a feature of PTAB adjudication would affect the broader administrative state.

Third, comparing PTAB adjudication with the diverse agency adjudications across the regulatory state can highlight deficiencies in the PTAB's decisional process while concomitantly providing ways for the agency to improve its own decision-making. Understanding which features most agency adjudications have that the PTAB lacks can help inform discussions as to why the Patent Office's adjudicatory powers lack this feature and what, if anything, should be done to rectify this issue. This could lead to improvements in the decision-making process at the PTAB and the Patent Office more generally. Conversely, the PTAB has embraced a number of best practices that are worth incorporating in other new-world adjudicatory processes. Much can be learned from examining these diverse laboratories of agency adjudication.

Finally, by focusing on these new PTAB proceedings and situating them within the new world of agency adjudication, we hope to spark a more sustained and critical debate about the future of agency adjudication. At the very least, administrative law, as taught in the classroom, must look beyond formal adjudication governed by the APA to the vast array of formal-like adjudications that predominate agency adjudication today. Yet even in this new world of agency adjudication, vesting final policy-making authority in the agency head remains a critical feature - one which sets agency adjudication apart from disputes resolved by the Article III judiciary or Article I legislative courts, provides improved agency performance, and merits further theoretical development and empirical investigation. This Article starts that conversation by examining in detail a new agency adjudication - PTAB adjudication-that expressly lacks final decision-making authority in the agency head.

This Article proceeds as follows: Part I provides an overview of both the lost world and the new world of agency adjudication. Part II introduces the key features of PTAB adjudication as set forth in the AIA. Part III situates the PTAB proceedings within the larger landscape of agency adjudications that take place

22. See, e.g., Stuart Minor Benjamin \& Arti K. Rai, Who's Afraid of the APA? What the Patent System Can Learn from Administrative Law, 95 GEO. L.J. 269, 270 (2007) ("In contrast to commentators and practitioners in other technically complex areas ... the patent law community has tended to pay little attention to administrative law."); Adam Mossoff, The Use and Abuse of IP at the Birth of the Administrative State, 157 U. PA. L. REV. 2001, 2002 (2009) ("Throughout the twentieth century, administrative law and intellectual property law seemed as if they were hermetically sealed off from each other in both theory and practice."). 
across the regulatory state. Part IV then focuses on one critical difference in PTAB adjudication that sets it apart- the agency head's lack of final decisionmaking authority.

\section{$\mathrm{I}$.}

\section{UNDERSTANDING MODERN AGENCY ADJUDICATION}

Every administrative law student learns about classic formal APA adjudication. This world of agency adjudication, however, is largely lost. Compared to classic formal APA adjudication, the modern landscape of agency adjudication is much more substantively and procedurally diverse and involves a variety of less-independent adjudicatory personnel. This Section describes this modern landscape and contrasts it with APA "formal" adjudication. Part I.A begins with the lost world of adjudication. Part I.B then introduces the new world of adjudication. Through this survey, an important similarity emerges: agency adjudication, whether part of the lost or new world, generally vests final decision-making authority in the agency head.

\section{A. The Lost World: APA-Governed Adjudication}

Enacted in 1946, the Administrative Procedure Act establishes the default rules for federal agency action and judicial review, ${ }^{23}$ subject to congressional override in the agency's governing statute. ${ }^{24}$ The APA divides the types of agency actions into two broad categories: (1) rulemaking, which is the agency process for promulgating rules that articulate "an agency statement of general or particular applicability and future effect"; ${ }^{25}$ and (2) adjudication, which is agency action that does not qualify as rulemaking. ${ }^{26}$

23. See 5 U.S.C. $\S \S 551-559,701-706$ (2012). For more on APA's enactment, see, for example, Walter Gellhorn, The Administrative Procedure Act: The Beginnings, 72 VA. L. REV. 219 (1986); George B. Shepherd, Fierce Compromise: The Administrative Procedure Act Emerges from New Deal Politics, 90 NW. U. L. REV. 1557 (1996). For an overview of the evolution of the APA since 1946, see, for example, Kathryn E. Kovacs, Superstatute Theory and Administrative Common Law, 90 IND. L.J. 1207 (2015); Christopher J. Walker, Modernizing the Administrative Procedure Act, 69 ADMIN. L. REV. 629, 633-68 (2017).

24. See, e.g., Dickinson v. Zurko, 527 U.S. 150, 154-55 (1999) (holding that to depart from the APA default rules, the agency's governing statute must suggest "more than a possibility of a [different] standard, and indeed more than even a bare preponderance of evidence"; and stating that the exception "must be clear"). See generally Stephanie Hoffer \& Christopher J. Walker, The Death of Tax Court Exceptionalism, 99 MINN. L. REV. 221, 243-45 (2014) (discussing the standards for departing from the APA's default rules).

25. 5 U.S.C. $\S 551(4)-(5)(2012)$.

26. Id. $\S 551(6)$ (defining adjudication as the "agency process for the formulation of an order"); $i d$. (defining an "order" as "the whole or a part of a final disposition ... of an agency in a matter other than rule making"). But see Ronald M. Levin, The Case for (Finally) Fixing the APA's Definition of "Rule," 56 ADMIN. L. REV. 1077 (2004) (noting that the APA's distinction between rulemaking and adjudication is confusing and arguing that the APA's definition of "rule" "may be the most blatantly defective provision in the Act"). 
The APA further distinguishes "formal" adjudication from all other types of "informal" adjudication. The APA's formal adjudication procedures generally apply "in every case of adjudication required by statute to be determined on the record after opportunity for an agency hearing." ${ }^{27}$ In such circumstances, the APA requires a number of trial-like procedures similar to a bench trial in federal court, subject to modification in the agency's governing statute. Richard Pierce's Administrative Law Treatise identifies ten key statutory requirements of APAgoverned formal adjudication, which are summarized in Table $1 .^{28} \mathrm{We}$ add an eleventh important feature-final decision-making authority in an agency head-which is discussed below.

Table 1. Classic APA-Governed Formal Adjudication

\begin{tabular}{|c|c|c|}
\hline & Statutory Requirement & APA Provision \\
\hline 1. & $\begin{array}{l}\text { Notice of Legal Authority and Matters of Fact and Law } \\
\text { Asserted }\end{array}$ & $\S 554(b)$ \\
\hline 2. & $\begin{array}{l}\text { Oral Evidentiary Hearing Before the Agency or ALJ } \\
\text { Who Must Be Impartial }\end{array}$ & $\S 556(b)$ \\
\hline 3. & $\begin{array}{l}\text { Limitations on Adjudicator's Ex Parte Communications } \\
\text { with Parties and Within Agency }\end{array}$ & $\S \S 554(d), 557(d)(1)$ \\
\hline 4. & $\begin{array}{l}\text { Availability of Legal or Other Authorized } \\
\text { Representation }\end{array}$ & $\S 555(b)$ \\
\hline 5. & Burden of Proof on Order's Proponent & $\S 556(d)$ \\
\hline 6. & Party Entitled to Present Oral or Documentary Evidence & $\S 556(d)$ \\
\hline 7. & $\begin{array}{l}\text { Party Entitled to Cross-Examine Witnesses if Required } \\
\text { for Full Disclosure of Facts }\end{array}$ & $\S 556(d)$ \\
\hline 8. & Decision Limited to Bases Included in Hearing Record & $\S 556(d)$ \\
\hline 9. & $\begin{array}{l}\text { Party Entitled to Transcript of Evidence from Exclusive } \\
\text { Record for Decision }\end{array}$ & $\S 556(\mathrm{e})$ \\
\hline 10. & $\begin{array}{l}\text { Decision Includes Reasons for All Material Findings and } \\
\text { Conclusions }\end{array}$ & $\S 557(\mathrm{c})(3)(\mathrm{A})$ \\
\hline 11. & $\begin{array}{l}\text { Agency Head Final Decision-Making Authority and De } \\
\text { Novo Review of ALJ Decisions }\end{array}$ & $\S 557(b)$ \\
\hline
\end{tabular}

The first three requirements reflect due process concerns ensuring proper notice and a meaningful opportunity to be heard before an unbiased adjudicator. The APA requires that the parties subject to adjudication be provided with timely notice of the hearing, including "the legal authority and jurisdiction under which

27. 5 U.S.C. §554(a) (2012). The APA includes a half-dozen exceptions, including where the agency adjudication is subject to a trial de novo review, "proceedings in which decisions rest solely on inspections, tests, or elections," and "cases in which an agency is acting as an agent for a court." Id. $\S 554(\mathrm{a})(1)-(6)$.

28. 1 PIERCE, supra note 1, at 703 (discussing formal adjudication procedures set forth in 5 U.S.C. $\S \S 554-557)$. 
the hearing is to be held" and "the matters of fact and law asserted." ${ }^{29}$ An impartial adjudicator must preside over the evidentiary hearing. An impartial adjudicator means the agency, "one or more members of the body which comprises the agency," or "one or more administrative law judges appointed under" the APA. ${ }^{30}$ The adjudicator cannot engage in ex parte communications about the case "unless on notice and opportunity for all parties to participate." 31 Nor can the adjudicator "be responsible to or subject to the supervision or direction of an employee or agent engaged in the performance of investigative or prosecuting functions for an agency." 32

The APA provides four main requirements for the agency hearing. Parties may be represented by an attorney or, "if permitted by the agency, by other qualified representative." 33 In the proceeding, the proponent has the burden of proof, and the parties are entitled to present oral or documentary evidence, though "the agency as a matter of policy shall provide for the exclusion of irrelevant, immaterial, or unduly repetitious evidence." ${ }^{34}$ A party is also allowed to submit rebuttal evidence and "to conduct such cross-examination as may be required for a full and true disclosure of the facts." 35

The final three APA requirements featured in Pierce's treatise address the agency's order and decision. The agency's decision must be based exclusively on the record created at the hearing and supported by "reliable, probative, and substantial evidence." 36 If a party believes the agency's decision is based on a material fact outside of the record, the party must have an opportunity to make a timely request for reconsideration. ${ }^{37}$ Accordingly, the APA requires the agency to provide the parties with an "exclusive record" of "[ $\mathrm{t}] \mathrm{he}$ transcript of testimony and exhibits, together with all papers and requests filed in the proceeding." 38 Not only must the agency's decision be based solely on the exclusive record created at the hearing, but it must also include a statement of "findings and conclusions,

29. 5 U.S.C. $\$ 554$ (b) (2012). This notice requirement applies to the agency and private parties when they are the moving parties, though the APA expressly requires private parties to "give prompt notice of issues controverted in fact or law." Id.

30. Id. § 556(b) (2012); see also id. § 3105 ("Each agency shall appoint as many administrative law judges as are necessary for proceedings required to be conducted in accordance with sections 556 and 557 of this title."). The APA provides that parties may move to exclude administrative law judges for "personal bias or other disqualification of a presiding or participating employee." Id. § 556(b).

31. Id. §554(d)(1).

32. Id. $\S 554(\mathrm{~d})(2)$. Indeed, the APA has detailed prohibitions on ex parte communications "relevant to the merits of the proceeding," requirements to make any such communications part of the public record of the proceeding, and authority for the agency to require the offending party "to show cause why his claim or interest in the proceeding should not be dismissed, denied, disregarded, or otherwise adversely affected on account of such violation." Id. § 557(d).

33. Id. $\S 555(\mathrm{~b})$.

34. Id. $\S 556(\mathrm{~d})$.

35. Id.

36. Id.

37. Id. \$ 556(e)

38. Id. 
and the reasons or basis therefor, on all the material issues of fact, law, or discretion presented on the record." 39

Every administrative law casebook covers the basics of APA formal adjudication, focusing primarily on what process is required under the Constitution. ${ }^{40}$ Paradigmatic APA-governed formal adjudication requires an evidentiary hearing held before an ALJ in which parties are entitled to oral arguments, rebuttal, and cross-examination of witnesses. ALJs presiding over this formal adjudicatory hearing are functionally equivalent to a trial judge in a bench trial. The ALJ is the principal factfinder and initial decision-maker in an agency adjudication, and the APA generally empowers ALJs to "regulate the course of the hearing." ${ }^{41}$ Moreover, Congress has sharply limited agency control over the selection, retention, and removal of ALJs, such that ALJs enjoy strong decisional independence..$^{42}$

The critical difference between an ALJ adjudication and a civil bench trial is that the agency head has de novo review authority, while an appellate court defers to the trial court's factual findings. ${ }^{43}$ Indeed, federal courts scholars have long distinguished Article III federal courts and Article I legislative courts from agency adjudicatory tribunals on the theory that the agency head has final policy-

39. Id. $\S 557(\mathrm{c})(3)(\mathrm{A})$.

40. In the early years of the APA, the Supreme Court seemed to treat the APA's "formal" adjudication hearing provisions as constitutionally required under the Due Process Clause, only to quickly retreat from that position. See PIERCE, supra note 1, at 704-05 (discussing Wong Yang Sun v. McGrath, 339 U.S. 33 (1950), which was overruled in relevant part by Marcello v. Bonds, 349 U.S. 302 (1955)). Today, administrative law casebooks focus more on the balancing test articulated in Mathews v. Eldridge, 424 U.S. 319 (1976).

41. 5 U.S.C. § 556(c)(5) (2012).

42. While agencies may "appoint as many administrative law judges as are necessary" to handle their caseload, 5 U.S.C. $§ 3105$ (2012), agencies have historically been limited in selecting ALJs from a list of candidates selected by the Office of Personnel Management (OPM). But see Exec. Order 13,843, 83 Fed. Reg. 32,755 (July 13, 2018) (directing, in light of Lucia v. SEC, 138 S. Ct. 2044 (2018), that ALJs be exempted from the competitive hiring rules and examinations set forth by OPM and that federal agencies establish their own processes for hiring ALJs). Once appointed, ALJs have significant protection from performance reviews, as their financial compensation is not dependent upon the evaluation of their performance by the agency but instead set by statute and OPM regulations. 5 U.S.C. $\S 5372$ (2012). ALJs can only be removed for "good cause," as determined by an independent agency, the Merit Systems Protection Board, after a formal adjudicative hearing. Id. § 7521(a). Because ALJs do not serve a fixed time period, they in essence have life tenure. See generally Harold H. Bruff, Specialized Courts in Administrative Law, 43 ADMIN. L. REV. 329, 346 (1991); Jeffrey S. Lubbers, Federal Administrative Law Judges: A Focus on our Invisible Judiciary, 33 ADMIN. L. REV. 109, 11220 (1981); Paul R. Verkuil, Reflections Upon the Federal Administrative Judiciary, 39 UCLA L. REV. 1341, 1344 (1992).

43. See generally Merrill, supra note 2; Christopher J. Walker, Against Remedial Restraint in Administrative Law, 117 COLUM. L. REV. ONLINE 106, 111 (2017) ("The appellate review model in the civil litigation context is based on the record from the prior proceeding, and the reviewing court does not engage in independent fact-finding. Likewise, the standard of review reflects the comparative expertise of the various institutions, with more or less deferential review depending on whether the issue is more factual or legal, respectively."). 
making authority. ${ }^{44}$ As discussed in Part IV.A, given that agency-head final decision-making authority provides numerous benefits that improve agency performance, it is unsurprising that agency-head final decision-making authority is what Ron Levin has coined the "standard federal model." 45

In the Administrative Law Treatise, Pierce does not list agency-head final decision-making authority as one of the ten core features of APA-governed formal adjudication. Indeed, this feature has been underexplored in administrative law literature. ${ }^{46}$ But this agency-head final decision-making authority certainly deserves mention. The APA provides that, in cases where "the agency did not preside at the reception of the evidence, the presiding employee... shall initially decide the case," and that initial "decision then becomes the decision of the agency without further proceedings unless there is an appeal to, or review on motion of, the agency within time provided by rule." ${ }^{47}$ When the agency decides to review an initial decision - either on appeal or via sua sponte review - the agency head has final decision-making authority. ${ }^{48}$

Furthermore, the Supreme Court has interpreted the APA to provide that the ALJ's initial decision is not entitled to deferential administrative review. ${ }^{49}$ An agency has complete freedom, as though it had heard the initial evidence itself, when reviewing the decision of the ALJ. Nevertheless, the agency is typically required to explain why it has rejected an ALJ's findings, and courts examine the evidence more critically when an agency's reversal of an ALJ ruling turns on the credibility of the witnesses who testified at the hearing. ${ }^{50}$

This traditional APA-governed formal adjudication is utilized by a number of so-called independent federal agencies, such as the Federal Trade Commission, ${ }^{51}$ the Federal Communications Commission, ${ }^{52}$ the International Trade Commission, ${ }^{53}$ and the Securities and Exchange Commission. ${ }^{54}$ It is also

44. See, e.g., FALlON ET AL., supra note 8, at 379-80 (noting the policy-making function in agency adjudication); Fallon, supra note 8 , at 923-24 (same).

45. Levin, supra note 7, at 412.

46. An important exception is Russell L. Weaver, Appellate Review in Executive Departments and Agencies, 48 ADMIN. L. REV. 251 (1996). See also Shapiro, supra note 9, at 921 (noting how agency heads have "the power to formulate policy by either adjudication or the promulgation of regulations").

47. 5 U.S.C. $§ 557(b)(2012)$.

48. See Weaver, supra note 46, at 252 (noting that while the APA "imposed strict divisions between those who prosecute and those who adjudicate," it "imposed far fewer restraints on the appellate process; under the APA, ALJ decisions were fully reviewable within the agency").

49. FCC v. Allentown Broad. Corp., 349 U.S. 358, 364-65 (1955).

50. Universal Camera Corp. v. NLRB, 340 U.S. 474, 496 (1951). Most frequently, the agency head may reverse the ALJ's initial decision for policy reasons. However, when the agency reverses for factual disputes, the Court has stated that "evidence supporting a conclusion may be less substantial when an impartial, experienced [ALJ] who has observed the witnesses and lived with the case has drawn conclusions different from the [agency's]." Id.

51. 15 U.S.C. $\S 45$ (2012).

52. 47 U.S.C. $\$ 151$ (2012).

53. 19 U.S.C. $\S 1330$ (2012).

54. 15 U.S.C. $\S 78 \mathrm{~d}(2012)$. 
commonplace at a number of executive branch agencies, including at the Departments of Agriculture, Health and Human Services, Interior, and Labor. ${ }^{55}$

\section{B. The New World: Adjudication Outside of the APA}

Despite administrative law's fixation on APA-governed formal adjudication, the vast majority of agency adjudications and federal regulatory actions do not involve APA-governed formal adjudications before an ALJ or the agency itself. Instead, most agency actions are adjudicated by non-ALJ agency personnel that have diverse titles, such as administrative judge, administrative appeals judge, immigration judge, hearing officer, and presiding official—just to name a few. Some experts estimate that as much as 90 percent of all agency adjudication occurs outside of APA formal adjudication proceedings. ${ }^{56}$ As Michael Asimow observed, the APA "fails to regulate in any significant way the vast and rapidly increasing number of more or less formal evidentiary adjudicatory hearings required by federal statutes that are not conducted by ALJs and yet are functionally indistinguishable from the hearings that are conducted by ALJs." $" 57$

Kent Barnett explained that administrative judges (AJs) "remain the most unknown of the 'hidden judiciary' [because the] data for AJs, as compared to ALJs is much more limited, dated, and inconsistent from survey to survey." 58 But there are three relatively extensive surveys from 1992, 2002, and 2017 that provide some context on the scope of adjudicatory activities outside of the APA. For instance, in 2002, agencies reported that they conducted more than 550,000 adjudications annually outside of the APA-governed formal adjudication process, a 41 percent increase from the 1992 survey. ${ }^{59}$ In 2002, there were also 3,370 non-ALJ adjudicators, a 25 percent increase from 2,692 non-ALJ adjudicators in $1992 .{ }^{60}$ By comparison, there were only 1,351 ALJs in 2002 and 1,167 ALJs in $1992 .{ }^{61}$ By 2017 , there were 10,831 non-ALJ adjudicators in the

\footnotetext{
55. OfFice OF PersonNel MgMt., Administrative LAW Judges, https://www.opm.gov/services-for-agencies/administrative-law-judges/\#url=ALJs-by-Agency [https://perma.cc/LJ8D-HNDZ] (last visited Dec. 21, 2018). OPM provides an agency-by-agency breakdown of ALJs on its website.

56. AM. BAR ASS'N, A GUIDE TO FEDERAL AGENCY ADJUDICATION 176 (Jeffrey B. Litwak ed., 2d ed. 2012) (citing Paul R. Verkuil, A Study of Informal Adjudication Procedure, 43 U. CHI. L. REV. 739, 741 (1976)).

57. Michael Asimow, The Spreading Umbrella: Extending the APA's Adjudication Provisions to All Evidentiary Hearings Required by Statute, 56 ADMIN. L. REV. 1003, 1020 (2004).

58. Kent Barnett, Against Administrative Judges, 49 U.C. DAVIS L. REV. 1643, 1656-57 (2016).

59. RAYMOND LIMON, OFFICE OF ADMIN. L. JUDGES, THE FEDERAL JUDICIARY THEN AND NOW-A DECADE OF CHANGE 1992-2002, at 3 (2002) (comparing 2002 survey data with findings from John H. Frye III, Survey of Non-ALJ Hearing Programs in the Federal Government, 44 ADMIN. L. REV. $261(1992))$.

60. Id.

61. Id. at 3 n. 4 .
} 
surveyed agencies. ${ }^{62}$ In contrast, the Office of Personnel Management (OPM) reports that there were 1,965 ALJs across the federal administrative state as of March 2017, 85 percent of whom work at the Social Security Administration. ${ }^{63}$ The non-ALJ workforce is five times as large as the ALJ workforce.

Moreover, there is great breadth and diversity in non-APA agency adjudications. The Administrative Conference of the United States (ACUS) has exhaustively documented that diversity, observing that these adjudications

involve types of matters spanning many substantive areas, including immigration, veterans' benefits, environmental issues, government contracts, and intellectual property. Some involve disputes between the federal government and private parties; others involve disputes between two private parties. Some involve trial-type proceedings that are at least as formal as [APA-governed "formal"] adjudication. Others are quite informal and can be decided based only on written submissions. Some proceedings are highly adversarial; others are inquisitorial. Caseloads vary. Some have huge backlogs and long delays; others seem relatively current. The structures for internal appeal also vary. ${ }^{64}$

The new world of agency adjudication is further complicated by the array of agency adjudicatory proceedings that not only fall outside of APA-governed "formal" adjudication but also do not even involve an agency-administrated evidentiary hearing. The 1992, 2002, and 2017 surveys of non-ALJ agency adjudicators primarily captured the agency officials who conduct evidentiary hearings, not the agency officials who engage in millions of less formal agency adjudications conducted each year. ${ }^{65}$ To provide one example, the IRS routinely makes tax deficiency determinations following an audit without a legally required evidentiary hearing. ${ }^{66}$ Although the number of IRS deficiency determinations is not publicly available, we know that the IRS audits or reviews around 5 percent — more than five million returns — of the tax returns filed each

62. BARNETT ET AL., supra note 13, at 16-17. This number includes 7,856 Patent Examiners at the Patent Office, compared to a reported 1,000 Patent Examiners in the 2002 Limon study. Id. at 18. If Patent Examiners are excluded from both surveys, we see an increase in non-ALJ adjudicators from 2,370 in the 2002 survey to 2,976 in the 2017 survey - a 26 percent increase in fifteen years.

63. Id.

64. Adoption of Recommendations, 81 Fed. Reg. 94,312, 94,315 (Dec. 23, 2016).

65. See Michael Asimow, Adjudication Outside the Administrative Procedure ACT 5 (Admin. Conf. U.S. ed., 2016) https://www.acus.gov/sites/default/files/documents/adjudicationoutside-the-administrative-procedure-act-draft-report.pdf [https://perma.cc/N949-VKRM] ("Two earlier studies by John Frye and Ray Limon sought to map the world of Type B adjudication. ... The studies take snapshots of Type B adjudications in 1992 and again in 2002.").

66. See Hoffer \& Walker, supra note 24, at 235-37 (describing the IRS tax deficiency adjudicatory process and subsequent judicial review). A second example of IRS informal adjudication involves its review of innocent spouse claims. See id. at 237-40. A final IRS example concerns collections due process proceedings. See id. at 240-41. As Asimow explains, it is more difficult to categorize collection due process adjudications because tax regulations require the IRS to conduct a "hearing," but that hearing is quite informal. See AsIMOW, supra note 65, at 10 ("I originally included IRS CDP hearings as Type B adjudication, but have now decided that they are not 'evidentiary hearings.' Instead, they should be treated as Type C adjudication.”). 
year. ${ }^{67}$ And in fiscal year 2016, for instance, the IRS imposed civil penalties on nearly 40,000 filers. ${ }^{68}$

In light of these critical differences in "informal" adjudication, ACUS and the American Bar Association's Section of Administrative Law and Regulatory Practice have discouraged the use of the traditional, binary distinction between "formal" and "informal" for APA agency adjudication. ${ }^{69}$ Instead, they advocate for three categories of adjudication:

(a) Adjudication that is regulated by the procedural provisions of the Administrative Procedure Act (APA) and usually presided over by an administrative law judge (referred to as Type $\mathrm{A}$ in the report that underlies this recommendation and throughout the preamble);

(b) Adjudication that consists of legally required evidentiary hearings that are not regulated by the APA's adjudication provisions in 5 U.S.C. sections 554 and 556-557 and that is presided over by adjudicators who are often called administrative judges, though they are known by many other titles (referred to as Type B in the report that underlies this recommendation and throughout the preamble); and

(c) Adjudication that is not subject to a legally required (i.e., required by statute, executive order, or regulation) evidentiary hearing (referred to as Type $\mathrm{C}$ in the report that underlies this recommendation and throughout the preamble). ${ }^{70}$

Type A adjudication is the same as APA-governed "formal" adjudication discussed in Part I.A. Type B adjudication generally tracks adjudications conducted by the non-ALJ adjudicators discussed in the 1992, 2002, and 2017 surveys - administrative adjudications where a statute, regulation, or executive order requires an evidentiary hearing that is not governed by the APA's extensive adjudication provisions. ${ }^{71}$ Type $\mathrm{C}$ adjudication is a residual category for less formal adjudications that do not require an evidentiary hearing.

67. See, e.g., TAXPAYER ADVOCATE SERVICE, 2016 ANNUAL REPORT TO CONGRESS 28 fig.S.6 (2016), https://taxpayeradvocate.irs.gov/Media/Default/Documents/2016-ARC/ARC16_Volume1.pdf [https://perma.cc/Y7WY-D8VQ] (reporting that the IRS audited or reviewed to some extent 6,825,987 of the 146,777,623 returns filed in 2014).

68. Id. at 42 tbl.7.

69. See Adoption of Recommendations, 81 Fed. Reg. 94,312, 94,314-15 (Dec. 23, 2016) (distinguishing Type A, B, and C adjudications); accord AMERICAN BAR ASS'N, RESOLUTION 114 (Feb. 2005) [hereinafter ABA RESOLUTION https://www.americanbar.org/content/dam/aba/administrative/administrative_law_judiciary/resolution _114.authcheckdam.pdf [https://perma.cc/BK94-7UZ2]. See generally Asimow, supra note 57 (presenting and discussing further ABA Resolution 114).

70. Adoption of Recommendations, 81 Fed. Reg. at 94,314 (footnotes omitted).

71. See AsIMOW, supra note 65, at 2. As Asimow explains, distinguishing Type B adjudications from both Type A and Type C adjudications is not an exact science. See id. at 7-13. For many Type B adjudications, the relevant statute may not indicate whether the APA's formal adjudication provisions should apply. Asimow identifies four ways to distinguish Type B from Type A: (1) whether the relevant statute uses the APA's magic words "on the record" after an agency hearing, 5 U.S.C. § 554(a) (2012); (2) whether the relevant statute does not use the magic words but otherwise assumes record exclusivity and requires an evidentiary hearing; (3) whether courts apply Chevron deference to agency statutory 
Scholars have been studying non-APA adjudications for at least four decades, although the emergence of this new typology is of relatively recent vintage. In 1976, Paul Verkuil surveyed the variety of informal adjudications (Type B and Type C) and explored constitutional due process issues. ${ }^{72}$ Before that, several scholars had attempted to categorize and identify best practices for what agency adjudication scholars call Type $\mathrm{C}$ adjudication. ${ }^{73}$ However, it was not until the 1990s that scholars drew the distinction between Type A and Type B adjudication. In 1992, ACUS published a report by Paul Verkuil, Daniel Gifford, Charles Koch, Richard Pierce, and Jeffrey Lubbers that focused on these distinctions. ${ }^{74}$ In 2005, the ABA passed a resolution that urged Congress to amend the APA to apply most of the APA's formal adjudication provisions to Type $\mathrm{B}$ adjudication. ${ }^{75}$

In 2015, ACUS, in collaboration with Stanford Law School, launched an online database of federal agency adjudication that, at its inception, covered over 133 federal agencies and 159 major adjudicatory schemes. ${ }^{76}$ Using this database, ACUS embarked on the most ambitious study of Type B adjudication to date, with a particular focus on identifying best practices for Type B adjudication. ${ }^{77}$ We return to these best practices in Part III.B when examining the PTAB process in greater detail. In the ACUS report, Asimow provided ten case studies of Type $B$ adjudications that give important context and texture about the variety of Type $B$ agency adjudication. For example, Asimow explained how the Department of Agriculture utilizes Type B adjudications to resolve disputes between businesses in the fruit and vegetable markets, ${ }^{78}$ how the Department of Energy uses Type B procedures to resolve personnel security and whistleblowing claims, ${ }^{79}$ how the

interpretations developed in the adjudication; and (4) whether courts determine congressional intent to have the APA apply due to the adjudication of serious public policy issues. See AsIMOW, supra note 65, at 7-9. Like Asimow, we do not take a definitive position here on the best criteria for distinguishing Type A from Type B, although some version of the second option seems reasonable, coupled with either the use of an ALJ or final review by the head of the agency.

72. Verkuil, supra note 56, at 757-92.

73. See, e.g., William J. Lockhart, The Origin and Use of "Guidelines for the Study of Informal Action in Federal Agencies, ” 24 ADMIN. L. REV. 167 (1972); Warner W. Gardner, The Procedures by Which Informal Action Is Taken, 24 ADMIN. L. REV. 115 (1972).

74. Paul R. Verkuil et al., Recommendation 92-7: The Federal Administrative JUDICIARY (Admin. Conf. of U.S. ed., 1992), https://www.acus.gov/sites/default/files/documents/927_0.pdf [https://perma.cc/3VXB-K362].

75. See ABA RESOLUTION 114, supra note 6; see generally Asimow, supra note 57 (presenting and discussing ABA Resolution 114).

76. Adjudication Research: Joint Project of ACUS and Stanford Law School, STANFORD UNIV., acus.law.stanford.edu [https://perma.cc/6CGX-8593] (last visited Dec. 21, 2018).

77. This project culminated with Asimow's report and recommendations of best practices, see Adoption of Recommendations, 81 Fed. Reg. 94,312, 94,314-16 (Dec. 23, 2016), which ACUS adopted in December 2016. ACUS ultimately adopted thirty-one recommendations that agencies should consider implementing when conducting Type $\mathrm{B}$ adjudication, including recommendations on the integrity of the decision-making process, prehearing practices, hearing practices, post-hearing practices, and effective management of procedures. Id. at 94, 315-16.

78. See Asimow, supra note 65, at 36-39 app. A-1.

79. See id. at 43-51 app. A-3. 
Equal Employment Opportunity Commission engages in Type B adjudication to resolve employment discrimination disputes brought by employees at certain federal agencies, ${ }^{80}$ and how the Environmental Protection Agency conducts Type B adjudications to address cases involving minor civil penalties or permitting requests. ${ }^{81}$

Similar to Type A adjudication discussed in Part I.A, a common feature of Type $\mathrm{B}$ adjudication is that the agency head has final decision-making authority. Although the APA does not require it for Type B adjudication (as it does for Type $\mathrm{A}$ adjudication), in the vast majority of Type $\mathrm{B}$ adjudication models, the agency head has some degree of decision-making authority. The 2017 ACUS survey found only thirteen types of non-ALJ trial-like hearings where there is no administrative appeal: "The matters in which the non-ALJ could issue a final decision without the possibility of any appellate review were limited to CFTC wage-garnishment proceedings, labor arbitrations within the Alcohol and Tobacco Tax and Trade Bureau of Treasury, public/private partnerships with NASA, and certain license-transfer agreements before the NRC." ${ }^{82}$ Out of Asimow's ten in-depth case studies, only the Civilian Board of Contract Appeals and the Board of Veterans Appeals, plus the PTAB, lacked higher-level agency reconsideration. ${ }^{83}$ In Part III.C and Part IV, we explore in much greater detail the importance of agency-head review in Type B adjudication, including the numerous benefits associated with agency-head final decision-making authority.

II.

\section{THE PTAB REVOLUTION}

In 2011, Congress created yet another new form of federal agency adjudication: certain proceedings before the PTAB at the Patent Office. ${ }^{84}$ The Leahy-Smith America Invents Act (AIA), which represents the most significant overhaul to the patent system in nearly sixty years, created three novel procedures for private parties to challenge issued patents before the newlyformed PTAB. ${ }^{85}$

The AIA was enacted, in part, to respond to the growing criticism that the Patent Office issues too many invalid patents, which harms consumer welfare. ${ }^{86}$ While Article III courts can invalidate erroneous patents, the cost of patent litigation has skyrocketed over the past decade, hampering the ability of patent

80. See id. at 52-56 app. A-4.

81. See id. at 56-62 app. A-5.

82. BARNETT ET AL., supra note 13, at 35.

83. ASIMOW, supra note 65 , at 33.

84. Leahy-Smith America Invents Act, Pub. L. No. 112-29, 125 Stat. 284 (2011).

85. See id. $\S 6$ (codified at 35 U.S.C. $\S \S 311-319,321-329)$ (post-grant review proceedings), $\S 12$ (codified at 35 U.S.C. § 257) (supplemental examination), § 18 (codified at 35 U.S.C. § 321) (transitional program for covered business method patents).

86. Michael D. Frakes \& Melissa F. Wasserman, Does the U.S. Patent Office Grant Too Many Bad Patents?: Evidence from a Quasi-Experiment, 67 STAN. L. REV. 613, 621 (2015). 
holders with meritorious claims to challenge wrongly-issued patents in federal court. ${ }^{87}$ These new PTAB adjudicatory proceedings were designed to create a cheaper, faster alternative to district court patent litigation. ${ }^{88}$ Each proceeding provides third parties with a procedurally robust, streamlined way to contest the legitimacy of issued patents directly through the Patent Office.

A third party must file a petition with the Patent Office and pay a substantial fee, often in excess of $\$ 15,000$ if the proceeding is instituted. ${ }^{89}$ Although agency leadership decides whether to institute the proceeding based on the strength of the petition, the agency itself is not a party. ${ }^{90}$ Unlike prior Patent Office adjudicatory systems, these new proceedings involve two private parties (the challenger and the patent owner) disputing the validity of a granted patent. ${ }^{91}$

More specifically, the AIA provides that the PTAB oversees three new, fast-track proceedings for the agency to reconsider its patent grants: Inter Partes Review (IPR), ${ }^{92}$ Post-Grant Review (PGR) ${ }^{93}$ and the transitional program for Covered Business Method Review (CBMR). ${ }^{94}$ Each proceeding has different eligibility criteria detailing who may file, when a petition may be filed, and the grounds on which a patent can be challenged. ${ }^{95}$ IPR and CBMR become available only after nine months of a patent grant, whereas PGR procedure is only for the nine months following a patent grant. ${ }^{96}$ As in federal court, a petitioner may argue any ground for invalidity in a PGR or CBMR proceeding, ${ }^{97}$ but in an IPR proceeding the Patent Office will only consider novelty or

87. Compare AM. InTELlectual Prop. LAW ASs'N, 2001 RePORT OF THE ECONOMY SURVEY (noting that for controversies ranging from ten to twenty-five million dollars the average costs through trial amount to \$797,000), with AM. INTELLECTUAL PROP. LAW ASS'N, 2015 REPORT OF THE ECONOMY SURVEY (noting that the average costs through trial were $\$ 3.5$ million for this same range).

88. The House Report on the AIA states that the Act intended to "convert[] inter partes reexamination from an examinational to an adjudicative proceeding" while establishing a new agency procedure known as post-grant review that "would take place in a court-like proceeding," H.R. REP. No. $112-98$, pt. 1 , at 46,68 (2011).

89. See 37 C.F.R. $\S \S 42.15(a)(1)$, (b)(2) (2018).

90. 35 U.S.C. § 314(a) (2012) (providing that the standard for instituting an inter partes review proceeding is a "reasonable likelihood that the petitioner would prevail with respect to at least [one] of the claims challenged in the petition"); 35 U.S.C. $\$ 324$ (2012) (providing that the standard for instituting a post-grant review proceeding is "[demonstrating] that it is more likely than not that at least [one] of the claims challenged in the petition is unpatentable").

91. Prior to the AIA, the Patent Office had limited procedures for reviewing granted patents known as ex parte and inter partes reexamination. Ex parte reexamination bars the participation of a third party once the Patent Office has determined whether a reexamination should commence. 37 C.F.R $\S 1.550(\mathrm{~g})$ (2018). Inter partes reexamination, which the AIA abolished, allowed for third-party participation but in a limited manner: the third party has the right to file written comments addressing "issues raised by the Office action or the patent owner's response." Id. § 1.947.

92. 35 U.S.C. $\$ 257$ (2012).

93. Id. $\S \S 311-319,321-329$.

94. Id. § 321.

95. See supra note 90 and accompanying text.

96. 35 U.S.C. $\S \S 311(\mathrm{c})(1) ; 321(\mathrm{c})(2012)$.

97. Id. $\S 321(\mathrm{~b})$. 
obviousness arguments based on patents or printed publications. ${ }^{98}$ While anyone can challenge the validity of a patent in IPR or PGR, only a party that has been charged with infringement of an eligible business method patent can initiate a CBMR challenge. ${ }^{99}$

Despite these differences, all three proceedings share a host of common features that make them viable alternatives to litigation in federal courts and distinguish them from the Patent Office's prior adjudicatory system. ${ }^{100}$ Perhaps most saliently, the AIA requires PTAB adjudication to take place in an adversarial, court-like hearing, in which parties are entitled to oral argument and discovery. ${ }^{101}$ The AIA also calls for the Patent Office to promulgate regulations regarding other trial-type features, such as prescribing sanctions for attorney misconduct ${ }^{102}$ and providing protective orders governing the exchange of confidential information. ${ }^{103}$ The regulations governing these new proceedings require that the Federal Rules of Evidence apply. ${ }^{104} \mathrm{~A}$ panel of at least three APJs with scientific expertise conducts the initial review of the patent and makes the trial-level determination. ${ }^{105}$

Although these new proceedings differ in dramatic ways from the Patent Office's prior adjudicatory powers, they do share at least one feature with PTAB's predecessor: there is no Director-level reconsideration of the Board's

98. Id.

99. Id. §314(a).

100. Wasserman, supra note 20.

101. See infra note 104 .

102. 35 U.S.C. $\S \S 316(a)(6), 326(a)(6)(2012)$.

103. Id. $\S 316(\mathrm{a})(7), 326(\mathrm{a})(7)$.

104. 37 C.F.R. $\$ 42.62$ (2018). See infra note 133 and accompanying text.

105. 35 U.S.C. $\S 6(a)-(b)(1)$ (2012). While having APJs, rather than patent examiners, preside over the proceedings increases the court-like nature of these novel adjudications, APJs are not afforded the same level of insulation from agency control and hence have arguably less independence in decisionmaking than ALJs. An outside agency, such as the OPM, is involved in the selection process of ALJs. The Patent Office, by contrast, interviews and makes recommendations about potential hires to the Director of the Patent Office and then to the Secretary of Commerce, who ultimately approves the candidate. U.S. PATENT \& TRADEMARK OFFICE, PTAB BROCHURE, https://www.uspto.gov/sites/default/files/documents/ptab_brochure_v2_4_10_14.pdf

[https://perma.cc/AJF7-VDGX] (last visited Dec. 21, 2018). To the Patent Office's credit, the agency appears to utilize a competitive process to hire APJs, requiring them to have both legal and technical degrees, active bar membership in good standing, and preferably ten to fifteen years of patent litigation or prosecution experience. Jennifer R. Bush, Administrative Patent Judges: Not Your Typical Federal Judge, DAILY J. (July 10, 2014). Once appointed, however, APJs also have less independence than ALJs from their agency-employers. Unlike ALJs, whose salaries are set by an outside agency, the Director of the Patent Office has the power to "fix the rate of basic pay for the administrative patent judges." 35 U.S.C. §3(b)(6) (2012). APJs are also subject to performance appraisals within the Patent Office and can receive bonuses, see U.S. PATENT \& TRADEMARK OFFICE, PTAB BROCHURE, https://www.uspto.gov/sites/default/files/documents/ptab_brochure_v2_4_10_14.pdf

[https://perma.cc/AJF7-VDGX] (last visited Dec. 21, 2018), both of which OPM regulations forbid with respect to ALJs. 5 C.F.R. § 930.206 (2018) (OPM Regulation). Finally, APJs are more easily removed from office than ALJs. But see Michael Abramowicz \& John F. Duffy, Ending the Patenting Monopoly, 157 PA. L. REV. 1541, 1553 (2009) (noting the difficulties associated with firing Patent Office employees). 
decisions within the agency. ${ }^{106}$ Parties can request a rehearing by the Board, but the Director of the Patent Office does not have direct review authority over PTAB determinations. ${ }^{107}$ Instead, the aggrieved party can immediately appeal the PTAB decision to the Federal Circuit, which has near-exclusive jurisdiction over patent appeals. ${ }^{108}$ Although the Director does not have final decisionmaking authority, she can influence PTAB outcomes - as she could with PTAB's predecessor. ${ }^{109}$ In particular, the Director has the authority to designate panel members that she hopes share her views in an effort to influence PTAB determinations - a power that would appear to violate the APA if the APJs were, in fact, ALJs, who are afforded more protections. ${ }^{110}$

PTAB adjudication, in particular IPR, has proven immensely popular. Since late 2012, the Patent Office has received nearly 8,500 post-grant petitions - over three times the anticipated quantity. ${ }^{111}$ The agency has hired a record-breaking number of APJs to staff these proceedings, tripling the size of its adjudicatory workforce to nearly 300 APJs. ${ }^{112}$ It is undeniable that the PTAB volume of work pales in comparison to that of the Patent Office's prior internal adjudicatory board. ${ }^{113}$ For the first time since its inception, the Federal Circuit

106. PTAB's predecessor was the Board of Patent Appeals and Interferences (BPAI). America Invents Act of 2011, Pub. L. No. 112-29, 125 Stat. 284 (2011), § 7(a) (restructured the Board of Patent Appeals and Interferences as the Patent Trial and Appeal Board). Similar to PTAB, BPAI adjudicated in panels comprising at least three APJs. 35 U.S.C. § 6(a) (2000) ("The Director, the Deputy Director, the Commissioner for Patents, the Commissioner for Trademarks, and the administrative patent judges shall constitute the Board [of Patent Appeals and Interferences]"); id. § 6(b) (2000) ("Each appeal and interference shall be heard by at least three members of the Board of Appeals and Interferences, who shall be designated by the Commissioner."). However, BPAI proceedings were best characterized as Type $\mathrm{C}$ rather than Type $\mathrm{B}$ adjudication. They lacked the signature characteristics of formal or quasiformal adjudication, as they were examinational rather than adjudicative in nature. For instance, BPAI proceedings did not provide for evidentiary hearings or discovery. See Wasserman, supra 20, at 197478 (discussing the relative lack of formality associated with BPAI determinations).

107. 35 U.S.C. §6(c) (2012). Part IV.C.4 infra addresses the September 2018 revisions to the PTAB's standard operating procedures to provide for a new rehearing process by a "precedential opinion panel."

108. Id. § 141(c).

109. See infra Part IV.B.

110. 5 U.S.C. $§ 3105$ (2012) (“Administrative law judges shall be assigned to cases in rotation so far as practicable ...."); see supra note 105 and accompanying text.

111. U.S. Patent \& TRAdemark OfFice, Performance AND ACCOUNTABility RePORT, FISCAL YEAR 2013, at 23 (noting that the "tremendous inflow of new proceedings is higher than initially estimated"); U.S. PATENT \& TRADEMARK OFFICE, PERFORMANCE AND ACCOUNTABILITY REPORT, FISCAL YEAR 2014, at 3 (noting that PTAB "received nearly 1,500 petitions for AIA trials in FY 2014, which was three times the expected number); U.S. PATENT \& TRADEMARK OFFICE, PERFORMANCE AND ACCOUNTABILITY REPORT, FISCAL YEAR 2015, at 70; U.S. PATENT \& TRADEMARK OFFICE, PERFORMANCE AND ACCOUNTABILITY REPORT, FISCAL YEAR 2016, at 71.

112. See, e.g., BARNETT ET AL., supra note 13, at 22 (reporting 275 APJs in 2017); Gene Quinn, Chief Judge Rader Swears in New Administrative Patent Judges, IP WATCHDOG (Jan. 25, 2012), http://www.ipwatchdog.com/2012/01/25/chief-judge-rader-swears-in-new-administrative-patentjudges/id=21969 [https://perma.cc/DT4T-FH3E] (noting there were approximately 100 APJs in 2011).

113. The Patent Office's prior adjudicative board was named the Board of Patent Appeals and Trials. Michael Wagner, An Introduction to Administrative Patent Judges at the Patent Trial and Appeal Board, 62 FED. LAW. 36 (May 2015). 
has docketed more patent appeals arising from the Patent Office through PTAB proceedings than from the district courts. ${ }^{114}$

There is little doubt that these new adjudicatory proceedings have fundamentally changed the relationship between Article III patent litigation and the administrative state. The growing popularity of the PTAB proceedings has, for a substantial number of patents, shifted the venue of deciding a patent's validity from the district courts to the Patent Office. ${ }^{115}$ The scale of this shift is reflected in the creation of a new bar association dedicated to lawyers and stakeholders who appear before the $\mathrm{PTAB}^{116}$ and the explosion of conferencesboth academic and practitioner-focused-devoted to these new PTAB proceedings. ${ }^{117}$

However, the PTAB revolution has fostered substantial controversy. ${ }^{118}$ The federal judiciary is considering a number of legal challenges alleging PTAB violations of administrative law, regulatory practice, or the Constitution. ${ }^{119}$ The Supreme Court recently held that PTAB adjudication does not unconstitutionally revoke the private property rights of patent owners. ${ }^{120}$ While scholars have questioned PTAB's legitimacy, there has been no sustained analysis of the Patent Office's new adjudicatory powers in comparison to other agency adjudications. This comparison, as noted in the Introduction, provides numerous insights.

114. Rantanen, supra note 15.

115. Saurabh Vishnubhakat et al., Strategic Decision Making in Dual PTAB and District Court Proceedings, 31 BERKELEY TECH. L.J. 45, 49-50 (2016).

116. PTAB BAR ASS'N, http://www.ptabbar.org [https://perma.cc/6TB9-KRMK] (last visited Dec. 21, 2018). The PTAB Bar Association has approximately 900 members. E-mail from Kristen Leikwold, Assoc. Member Servs., PTAB Bar Ass'n, to Melissa F. Wasserman, Professor of Law, Univ. of Tex. Sch. of Law (Feb. 14, 2018, 11:09 AM CST) (on file with author).

117. See, e.g., PTAB Bar Ass'n Annual Conference, PTAB BAR Ass'N (Mar. 2018); Eighth Annual Patent Administrative Law Conference, AM. UNIV. WASH. COLL. OF LAW (Mar. 2018), https://www.wcl.american.edu/news-events/events/detail/6136 [https://perma.cc/S3LB-4X5X]; Perspectives on the PTAB: The New Role of the Administrative State in the Innovation Economy, ANTONIN SCALIA LAW SCH. OF GEORGE MASON UnIV. (Nov. 2017), https://cpip.gmu.edu/conferences/perspectives-on-the-ptab-conference [https://perma.cc/N5Z9ZNZT]; The Power of the PTAB: The New Authority in Patent Law, CHI.-KenT COLL. OF LAw, (October 2017), https://www.kentlaw.iit.edu/academics/conferences-and-lecture-series/ptab-2017 [https://perma.cc/P4FY-XE5C]; Is Administrative Review of Granted Patents Constitutional?, CTR. FOR INNOVATION POLICY AT DUKE LAW SCH. (Sept. 22, 2017) https://law.duke.edu/innovationpolicy/oilstates-and-the-pto [https://perma.cc/YHT4-RNYE].

118. See, e.g., Greg Dolin, Dubious Patent Reform, 56 B.C. L. REV. 881, $903-07$ (2015).

119. See, e.g., Cuozzo Speed Tech. v. Lee, 136 S. Ct. 2131, 2142 (2016) (holding that the Patent Office had the legal authority to adopt the broadest reasonable interpretation standard for claim construction for PTAB proceedings); Wi-Fi One, LLC v. Broadcom Corp., 878 F.3d 1364, 1367 (Fed. Cir. 2018) (en banc) (holding that the time-bar determinations under $\S 315$ (b) are appealable); Aqua Prod., Inc. v. Matal, 872 F.3d 1290 (Fed. Cir. 2017) (en banc) (holding in a fractured decision that the $\mathrm{PTAB}$ can no longer place the burden of establishing the patentability of amended claims on the patent owner in IPR proceedings).

120. Oil States Energy Servs., LLC v. Greene's Energy Grp., LLC, 138 S. Ct. 1365, 1370 (2018). 
III.

\section{SituAting PTAB AdJudicAtion Within the NeW WoRld OF AgENCY ADJUDICATION}

Part III situates the relatively new PTAB adjudication process within the new world of agency adjudication detailed in Part I.B. Part III.A explains how PTAB adjudication, while technically not APA-governed formal adjudication, nevertheless possesses most of the characteristics of such Type A adjudication. Part III.B compares PTAB adjudication to other types of Type B adjudications and demonstrates that PTAB adjudication embraces the vast majority of best practices that have been identified for any adjudication that requires an evidentiary hearing. Part III.C looks beyond the new world of agency adjudication to explore the ways in which PTAB adjudication differs from other types of Type B adjudications.

\section{A. PTAB Adjudication, the APA, and the Lost World}

Based on the statutory framework for the PTAB adjudication, PTAB is not technically a Type A, APA-governed formal adjudication, despite the Federal Circuit suggesting otherwise. ${ }^{121}$ As a result, the Federal Circuit's requirement that PTAB proceedings satisfy the APA formal adjudication procedures is legally misguided. To be sure, Congress in the AIA commanded the Patent Office Director to promulgate regulations that set forth a number of procedures, including "providing either party with the right to an oral hearing as part of the proceeding." 122 So a hearing is required, but Congress stopped short of using the magic language "on the record" with "an agency hearing,"123 which is the surefire way to signal that the APA's formal adjudication provisions apply. ${ }^{124}$

The clearest evidence against Type A classification, however, is that the AIA does not command that the agency's evidentiary hearing be presided over by the agency, "one or more members of the body which comprises the agency," or "one or more administrative law judges appointed under" the APA. ${ }^{125}$ To the contrary, the AIA instructs that these hearings be presided over by a threemember panel of "APJs"- - "persons of competent legal knowledge and scientific ability who are appointed by the Secretary [of Commerce], in consultation with the [Patent Office] Director." ${ }^{126}$ A second core difference, as explored in greater

121. See supra note 21 and accompanying text; infra note 137 and accompanying text (discussing Synopsys, Inc. v. Mentor Graphics Corp., 814 F.3d 1309 (Fed. Cir. 2016)).

122. See 35 U.S.C. § 316(a)(10) (2012) (for inter partes review); id. § 326(a)(10) (for post-grant review).

123. 5 U.S.C. $§ 554$ (a) (2012).

124. See supra note 71 and accompanying text.

125. 5 U.S.C. $\S 556(b)(2012)$.

126. 35 U.S.C. $\$ 6(a)$, (c) (2012). Moreover, when an agency’s enabling act utilizes the words "hearing" and "on the record," the agency must utilize formal adjudication to effectuate the proceedings in question. 5 U.S.C. $§ 554$ (a) (stating that "in every case of adjudication required by statute to be determined on the record after opportunity for an agency hearing" formal procedures outlined in $\S 554$ 
detail in Part III.C and Part IV, is that there is no direct appeal of a PTAB decision to the agency head.

Despite these differences, PTAB proceedings have many of the hallmarks of APA-governed formal adjudication. ${ }^{127}$ The Patent Office promulgated extensive regulations governing the conduct before the proceedings that include nearly all trial-type protections afforded formal adjudication outlined in the APA requirements. Table 2 compares the PTAB regulations with the APA's key "formal" adjudication requirements discussed in Part I.A and depicted in Table 1 .

In particular, the implementing regulations require that the parties receive notice from the agency of the trial ${ }^{128}$ and that parties serve certain notices on the agency and the parties. ${ }^{129}$ Indeed, the regulations explain that "[a] trial begins with a written decision notifying the petitioner and patent owner of the institution of the trial." ${ }^{130}$ Like the APA's formal adjudication provisions, the regulations prohibit ex parte communications ${ }^{131}$ and allow parties to be represented by counsel. ${ }^{132}$ The party seeking relief bears the burden of proof, and each party is entitled to present oral and documentary evidence through deposition and exhibits. ${ }^{133}$ Parties are entitled to cross-examine witnesses, but must do so via deposition and not at the hearing itself. ${ }^{134}$

and $\S \S 556-57$ are triggered); see also Melissa M. Berry, Beyond Chevron's Domain: Agency Interpretations of Statutory Procedural Provisions, 30 SEATTLE U. L. REV. 541, 551-52 (2006) (“[N]o one would dispute that formal procedures should be required if the enabling statute includes "on the record' language ...."). Like many other statutes, the AIA utilizes the term "hearing" without the phrase "on the record." See 35 U.S.C. § 326(a)(10) (2012) (providing, in post-grant review, "either party with the right to an oral hearing as part of the proceeding"); accord id. $\S 316$ (a)(10) (providing the same in inter partes review). While there is a split among the circuits as to whether the use of the word "hearing" alone is sufficient to trigger formal adjudication, the Patent Office has proceeded as if formal adjudication is required. See Wasserman, supra note 20, at 1978-89.

127. One of us has argued that the PTAB proceedings are formal enough to warrant strong deference for its legal interpretations of ambiguous terms in the Patent Act. Wasserman, supra note 20.

128. 37 C.F.R. $\S 42.4$ (2018).

129. Id. $\S 42.8$. The PTAB also has discretion to require parties to file a notice of the request for relief. $I d$. $\S 42.21$.

130. Id. $\S 42.2$.

131. Id. $\S 42.5(\mathrm{~d})$.

132. Id. $§ 1.31$.

133. See id. $\S 42.53$ (deposition testimony), $\S 42.63$ (all evidence as marked exhibits), $\S 42.65$ (expert testimony), $\S 42.70$ (oral argument and demonstrative exhibits).

134. Id. $\S 42.53$. 
Table 2. APA-Governed Formal Adjudication v. PTAB Adjudication

\begin{tabular}{|c|c|c|}
\hline & APA Statutory Requirement & Related PTAB Requirement \\
\hline 1. & $\begin{array}{l}\text { Notice of Legal Authority and } \\
\text { Matters of Fact and Law Asserted }\end{array}$ & $\begin{array}{l}\text { Yes (37 C.F.R. } \S \S 42.2,42.4,42.8,42.21 \\
(2018))\end{array}$ \\
\hline 2. & $\begin{array}{l}\text { Oral Evidentiary Hearing Before the } \\
\text { Agency or ALJ Who Must Be } \\
\text { Impartial }\end{array}$ & $\begin{array}{l}\text { Oral evidentiary hearing ( } 35 \text { U.S.C. } \$ \S \\
316,326(2018) \text { ), but before non-ALJ } \\
\text { "administrative patent judges" ( } 35 \text { U.S.C. } \\
\S 6(2018) \text { ) with no express provisions for } \\
\text { challenging impartiality }\end{array}$ \\
\hline 3. & $\begin{array}{l}\text { Limitations on Adjudicator's Ex } \\
\text { Parte Communications with Parties } \\
\text { and Within Agency }\end{array}$ & Yes (37 C.F.R. $\S 42.5(d)(2018))$ \\
\hline 4. & $\begin{array}{l}\text { Availability of Legal or Other } \\
\text { Authorized Representation }\end{array}$ & Yes (37 C.F.R. $\S \S 1.31,11.6(2018))$ \\
\hline 5. & $\begin{array}{l}\text { Burden of Proof on Order's } \\
\text { Proponent }\end{array}$ & Yes (37 C.F.R. $\S 42.20(c)(2018)$ ) \\
\hline 6. & $\begin{array}{l}\text { Party Entitled to Present Oral or } \\
\text { Documentary Evidence }\end{array}$ & $\begin{array}{l}\text { Yes (37 C.F.R. } \S \S 42.53,42.63,42.65 \text {, } \\
42.70(2018))\end{array}$ \\
\hline 7. & $\begin{array}{l}\text { Party Entitled to Cross-Examine } \\
\text { Witnesses if Required for Full } \\
\text { Disclosure of Facts }\end{array}$ & $\begin{array}{l}\text { Yes, via deposition not at hearing ( } 37 \\
\text { C.F.R. } \S 42.53 \text { (2018)) }\end{array}$ \\
\hline 8. & $\begin{array}{l}\text { Decision Limited to Bases Included } \\
\text { in Hearing Record }\end{array}$ & $\begin{array}{l}\text { Probably, as "[a]ll evidence must be filed } \\
\text { in the form of an exhibit" ( } 37 \text { C.F.R. } \S \\
42.63(\text { a) }(2018) \text { ) }\end{array}$ \\
\hline 9. & $\begin{array}{l}\text { Party Entitled to Transcript of } \\
\text { Evidence from Exclusive Record for } \\
\text { Decision }\end{array}$ & $\begin{array}{l}\text { No requirement in current regulations, } \\
\text { though parties must submit all evidence as } \\
\text { exhibits ( } 37 \text { C.F.R. } \S 42.63(\text { a) }(2018) \text { ) }\end{array}$ \\
\hline 10. & $\begin{array}{l}\text { Decision Includes Reasons for All } \\
\text { Material Findings and Conclusions }\end{array}$ & $\begin{array}{l}\text { Apparently no requirement in current } \\
\text { regulations ( } 37 \text { C.F.R. } \S \S 42.71-42.73 \\
(2018) \text { ) }\end{array}$ \\
\hline 11. & $\begin{array}{l}\text { Agency Head Final Decision- } \\
\text { Making Authority and De Novo } \\
\text { Review of ALJ Decisions }\end{array}$ & $\begin{array}{l}\text { No, the Patent Office Director lacks final } \\
\text { decision-making authority }\end{array}$ \\
\hline
\end{tabular}

The application of the remaining APA-governed formal adjudication provisions is less clear. The regulations provide no express mechanism, for instance, for disqualifying an APJ for bias - though in practice that occurs. ${ }^{135}$ The regulations do not expressly require that the PTAB decision be limited to bases included in the hearing record, ${ }^{136}$ that the parties be provided with a transcript of the evidence from the exclusive record for decision, or that the

135. Id.; see BARNETT ET AL., supra note 13, 49-50 (reporting PTAB adjudication among the agency adjudicative systems that have recusal requirements).

136. But see 37 C.F.R. $\S 42.63$ (a) (2018) (requiring that "[a]1l evidence must be filed in the form of an exhibit" and thus suggesting that the parties can only use evidence they submit to the agency). 
PTAB decision provide reasons for all material findings of fact and legal conclusions. The Federal Circuit, however, has required the PTAB to do so. ${ }^{137}$

Beyond the APA's mandated formal adjudication procedures, the implementing regulations also set forth general policies regarding other trialtype procedures, at least some of which are mandated by the AIA, such as imposing sanctions against a party for misconduct, ${ }^{138}$ compelling testimony and production, ${ }^{139}$ and allowing for expert testimony. ${ }^{140}$ The regulations also allow the parties to seek rehearing of a PTAB decision. ${ }^{141}$

\section{B. PTAB Adjudication Within the New World}

Although PTAB adjudication is not a Type A formal adjudication, it is at least a Type $\mathrm{B}$ formal adjudication because an evidentiary hearing is required. ${ }^{142}$ That's the easy question. The more difficult and important question is how PTAB adjudication compares to its Type B peers, in terms of procedural protections and other best practices.

This Subsection draws heavily on the extensive ACUS study on Type B adjudication, discussed in Part I.B, which focused on identifying best practices for these proceedings. ${ }^{143}$ ACUS ultimately adopted thirty-one recommendations that agencies should consider implementing when conducting Type B adjudication. ${ }^{144}$ In his report to ACUS, Asimow evaluated twenty of these best practices from the ten agencies comprising his detailed case studies, based on the "procedural regulations, manuals, or other sources of procedure law." ${ }^{145} \mathrm{He}$

137. See, e.g., Synopsys, Inc. v. Mentor Graphics Corp., 814 F.3d 1309, 1322 (Fed. Cir. 2016) (requiring the PTAB to meet the requirements of APA-governed formal adjudication including 5 U.S.C. $\S 557(\mathrm{c})(3)(\mathrm{A})$ which requires the adjudicative board to "include a statement of findings and conclusions, and the reasons or basis therefor, on all the material issues of fact, law, or discretion presented on the record").

138. 37 C.F.R. $§ 42.12$ (2018); see 35 U.S.C. $\$ 316(a)(6)$ (2012) (commanding the Patent Office Director to promulgate regulations for inter partes review proceedings that "prescribe[] sanctions for abuse of discovery, abuse of process, or any other improper use of the proceeding, such as to harass or to cause unnecessary delay or an unnecessary increase in the cost of the proceeding"); accord id. $\S 326(\mathrm{a})(6)$ (same for post-grant review proceedings).

139. 37 C.F.R. $\S 42.52$ (2018).

140. Id. $\S 42.65$.

141. Id. $\$ 42.71$ (d) ("A party dissatisfied with a decision may file a single request for rehearing. ...").

142. This was Asimow's conclusion as well: "The statute does not specifically provide for evidentiary hearings. In context, however, the statutory provisions calling for 'appeals,' 'reviews,' and 'proceedings,' require evidentiary hearings, although ... these hearings are based entirely on written evidence. Therefore, PTAB conducts Type B adjudication." ASIMOW, supra note 65, at 72. If one were to quibble with Asimow's reasoning, one could more forcefully argue that the statute itself requires evidentiary hearings, as the AIA requires the Patent Office Director to promulgate regulations for the submissions of evidence and development of the record, including "providing either party with the right to an oral hearing as part of the proceeding." See 35 U.S.C. § 316(a)(10) (for inter partes review); id. $\S 326(\mathrm{a})(10)$ (for post-grant review).

143. See AsimOW, supra note 65, at 17-35.

144. See Adoption of Recommendations, 81 Fed. Reg. 94,312, 94,314-16 (Dec. 23, 2016).

145. AsIMOW, supra note 65, at 33. 
found that the PTAB had already incorporated fourteen of the twenty best practices, where the other agencies incorporated between seven and nineteen best practices with a mean of 14.4 and a median of $14.25 .^{146}$ Table 3 depicts Asimow's findings about the PTAB's incorporation of these best practices, with two exceptions. While Asimow concluded, based on the regulations and manuals at the time of his study, that the PTAB lacked open and videoconference hearings, this is no longer the case. As a result, we determine that PTAB has incorporated sixteen of the twenty best practices, well above the mean and median values reported in Asimow's study.

As Table 3 illustrates, these twenty best practices are not of equal value, such that ranking the ten agencies based on raw numbers can be misleading. The PTAB has incorporated almost all of the most important procedural protections that ACUS has recommended. Concerning the integrity of the decision-making process, PTAB decisions are based on an exclusive record of decision, ban ex parte communications and separate the functions between the decision-makers and adversaries within the agency (this is not an issue in PTAB proceedings as the adversaries are the parties, not the agency). As for prehearing procedures, the PTAB requires written notice of the issues to the parties and a pretrial conference. PTAB prehearing procedures also allow for electronic document filing, pretrial discovery, and subpoena power for uncooperative witnesses. PTAB has open hearings ${ }^{147}$ and offers videoconference hearings upon request. ${ }^{148}$ The PTAB hearing procedures use APJs who issue written decisions, the Federal Rules of Evidence apply, and the parties have an opportunity to rebut. Posthearing procedures also involve written decisions, and a complete statement of the important procedures is publicly available.

146. Id. at 33 tbl.3. Asimow actually reports only thirteen best practices because he consolidates PTAB and Trademark Trial and Appeal Board (TTAB) trial and appellate adjudications, and he gives half credit for two best practices because the appellate adjudications (not at issue here) do not incorporate them, whereas the PTAB trial adjudications do. See id. at 33 n. 128 \& tbl.3.

147. Public Hearings Before the Patent Trial and Appeal Board (PTAB), USPTO https://www.uspto.gov/patents-application-process/patent-trial-and-appeal-board/hearings/publichearings-patent-trial-and [https://perma.cc/4AUE-XQBX] (last visited Dec. 22, 2018).

148. Video \& Telephonic Hearings, USPTO, https://www.uspto.gov/page/video-and-telephonichearings [https://perma.cc/7CRC-4GXX] (last visited Dec. 22, 2018); Hearings, USPTO [hereinafter USPTO Hearings], https://www.uspto.gov/patents-application-process/patent-trial-and-appealboard/hearings [https://perma.cc/QD86-6E2R] (last visited Dec. 22, 2018). The PTAB does not "create or provide any electronic recording of oral hearings," but court reporters transcribe each hearing and post transcripts on PTAB's website around two to three weeks after the hearing. Oral Hearing Transcripts, USPTO, https://www.uspto.gov/page/oral-hearing-transcripts [https://perma.cc/822TAMQY] (last visited Dec. 22, 2018). 
Table 3. PTAB Type B Best Practices

\begin{tabular}{|c|c|c|}
\hline \multicolumn{2}{|r|}{ ACUS Recommendation } & $\begin{array}{c}\text { PTAB } \\
\text { Incorporation }\end{array}$ \\
\hline \multicolumn{3}{|c|}{ Integrity of the Decision-making Process } \\
\hline 1. & Exclusive of the Record & Yes \\
\hline 2. & $\begin{array}{l}\text { Disqualification Mechanism for } \\
\text { Adjudicator Bias }\end{array}$ & No \\
\hline 3. & $\begin{array}{l}\text { Ban on Outsider Ex Parte } \\
\text { Communications }\end{array}$ & Yes \\
\hline 4. & $\begin{array}{l}\text { Separation of Adversary-Decisional } \\
\text { Functions }\end{array}$ & Yes \\
\hline \multicolumn{3}{|c|}{ Prehearing Procedures } \\
\hline 5. & Written Notice of Issues in Case & Yes \\
\hline 6. & Allowance for Lay Representation & No \\
\hline 7. & Alternative Dispute Resolution & No \\
\hline 8. & Pre-Trial Conference & Yes \\
\hline 9. & Electronic Document Filing & Yes \\
\hline 10. & Pre-Trial Discovery & Yes \\
\hline 11. & Subpoena Power & Yes \\
\hline 12. & Open Hearings & Yes \\
\hline \multicolumn{3}{|c|}{ Hearing Procedures } \\
\hline 13. & Use of Administrative Judges & Yes \\
\hline 14. & Videoconference Hearings & Yes \\
\hline 15. & Written-Only Opinions & Yes \\
\hline 16. & Evidentiary Rules & Yes \\
\hline 17. & Opportunity for Rebuttal & Yes \\
\hline \multicolumn{3}{|c|}{ Post-Hearing Procedures } \\
\hline 18. & Written Decisions & Yes \\
\hline 19. & Higher-Level Reconsideration & No \\
\hline \multicolumn{3}{|c|}{ Procedural Regulations } \\
\hline 20. & $\begin{array}{l}\text { Complete Statement of Important } \\
\text { Procedures }\end{array}$ & Yes \\
\hline
\end{tabular}

As for the four missing best practices, first, the PTAB does not have a formal procedural mechanism for parties to move to disqualify patent administrative law judges for bias. The 2017 ACUS survey of Type B adjudications revealed that roughly half (twenty out of thirty-one) of Type B adjudications reported in the survey had incorporated formal procedures and 
standards for disqualification and removal by regulation or by statute. ${ }^{149}$ The importance of impartiality - and the sensitivity involved when a party requests that an adjudicator recuse herself-strongly counsel that the PTAB codify by regulation (or at least formal guidance) the standards and procedures for disqualification. ${ }^{150}$ Second, PTAB does not provide for alternative dispute resolution. Third, while PTAB regulations permit parties to be represented by a registered patent attorney or registered non-attorney patent agent, they do not provide for unregistered lay representation. ${ }^{151}$ Fourth, although the PTAB regulations permit petitions for rehearing of PTAB decisions, such rehearing petitions are not decided by a higher-level body but instead, if granted, reheard by the PTAB itself. As further discussed in Part IV, the Patent Office Director does have some power to influence rehearing by ordering it and deciding which PTAB members serve on the panel. But, the Director cannot decide the case herself.

In sum, the Patent Office has already codified most of the best practices ACUS has recommended for Type B adjudication by regulation. It would probably be wise for the Patent Office to more expressly codify the exclusive record rule, as well as implement regulations to provide procedures for disqualification of APJs and formalized alternative dispute resolution procedures. The most critically-needed improvement, however, concerns higherlevel reconsideration by the Patent Office Director. We return to that issue in Part III.C, and then in even greater detail in Part IV.

\section{PTAB Adjudication Beyond the New World}

This Section so far has focused on the extent to which PTAB adjudication possesses the core features of APA-governed formal adjudication (Part III.A) and has embraced the best practices of Type B adjudication (Part III.B). Part III.C looks beyond the new world of agency adjudication to underscore the ways in which PTAB adjudication departs from a typical Type B adjudication. We focus on five differences. For the first four we merely introduce them and call for further empirical examination and theoretical development. The last difference - the lack of agency-head final decision-making authority-is examined in more detail, and then further explored in Part IV.

149. BARNETT ET AL., supra note 13, at 49.

150. ASIMOW, supra note 65, at 18 ("Procedural regulations and manuals should spell out this standard and explain how and when parties should raise bias claims. Some Part B procedural regulations do not contain explicit provisions concerning bias or explain how and when bias claims should be raised.").

151. See 37 C.F.R. $\S \S 1.31,11.6,41.5(a), 42.10$ (c) (2018). A patent agent is an individual who has passed the US Patent and Trademark Office's Patent bar but does not necessarily have a law degree. General Requirements Bulletin, §11.6(b), U.S. PATENT \& TRADEMARK OfFICE (July 30, 2018), https://www.uspto.gov/sites/default/files/documents/OED_GRB.pdf [https://perma.cc/DSE6-F6EL] (last visited Dec. 22, 2018). 


\section{PTAB Departures from Typical Type B Adjudication: Call for Further Research}

There are at least four differences between the PTAB and typical Type B adjudication that merit additional theoretical mooring and empirical analysis. This Section introduces these four dissimilarities.

Agency Private Enforcement Actions. Perhaps the unique feature of PTAB adjudication that has received the most attention to date is that PTAB adjudication involves agency adjudication of disputes between private parties, as opposed to adjudication of disputes between the government and a private party. Agency adjudication usually occurs in the context of adjudicating public benefits (e.g., immigration, Social Security, and veterans' benefits).

Although agency adjudication of private enforcement actions may be less common and more of a modern innovation, PTAB adjudication is not a complete outlier. The Interstate Commerce Commission, for instance, originally adjudicated claims between shippers and other private parties. ${ }^{152}$ In the seminal Crowell v. Benson decision, the Supreme Court in 1932 provided a constitutional basis for the current authority of administrative agencies to adjudicate certain private disputes. ${ }^{153}$ Frye's 1992 survey of non-ALJ adjudications identifies a number of other examples of private enforcement actions via agency adjudication. ${ }^{154}$ The Trademark Trial and Appeal Board (TTAB), which adjudicates the validity of federally registered trademarks between two private parties, is another example. ${ }^{155}$

Perhaps the most well-known example of agency adjudication of private enforcement actions involves the Commodity Futures Trading Commission (CFTC), as it was involved in CFTC v. Schor. ${ }^{156}$ As the Supreme Court explained

152. See, e.g., FTC v. Klesner, 280 U.S. 19, 26 n.3 (1929) (citing and discussing statutes that allowed "private individuals the right to institute proceedings and upon the administrative tribunal [of the Interstate Commerce Commission] the power to award reparations").

153. Crowell v. Benson, 285 U.S. 22, 51 (1932) ("The present case does not fall within the categories just described but is one of private right, that is, of the liability of one individual to another under the law as defined. But in cases of that sort, there is no requirement that, in order to maintain the essential attributes of the judicial power, all determinations of fact in constitutional courts shall be made by judges."). But see Stern v. Marshall, 564 U.S. 462, 489 n.6 (2011) ("Although the Court in Crowell went on to decide that the facts of the private dispute before it could be determined by a non-Article III tribunal in the first instance, subject to judicial review, the Court did so only after observing that the administrative adjudicator had only limited authority to make specialized, narrowly confined factual determinations regarding a particularized area of law and to issue orders that could be enforced only by action of the District Court. In other words, the agency in Crowell functioned as a true 'adjunct' of the District Court." (citations omitted)); see also id. at 504-05 (Scalia. J., concurring) ("Leaving aside certain adjudications by federal administrative agencies, which are governed (for better or worse) by our landmark decision in Crowell v. Benson, in my view an Article III judge is required in all federal adjudications, unless there is a firmly established historical practice to the contrary." (citation omitted)).

154. John H. Frye III, Survey of Non-ALJ Hearing Programs in the Federal Government, 44 ADMIN. L. REV. 261, 309-10 (1992).

155. See ASIMOW, supra note 65 , at 76-79 (providing a case study on TTAB adjudication).

156. CFTC v. Schor, 478 U.S. 833 (1986). 
in Schor, Congress charged the CFTC with "the administration of a reparations procedure through which disgruntled customers of professional commodity brokers could seek redress for the brokers' violations of the Act or CFTC regulations." 157 The Schor Court held that "the limited jurisdiction that the CFTC asserts over state law claims as a necessary incident to the adjudication of federal claims willingly submitted by the parties for initial agency adjudication does not contravene separation of powers principles or Article III."158

Moreover, the 2017 ACUS survey identified at least a half-dozen other examples from the Type B adjudication context ${ }^{159}$ : The Agricultural Marketing Service at the US Department of Agriculture (USDA) adjudicates disputes between private parties over produce and livestock. The Labor Department's Benefits Review Board adjudicates certain benefits disputes between employees, employers, or carriers. The Federal Maritime Commission adjudicates certain informal, small-dollar claims between private parties. The Library of Congress adjudicates royalty-rate disputes - both determination claims and distribution claims. The National Labor Relations Board adjudicates a number of disputes between employers, employees, and unions. And, the Peace Corps adjudicates sexual misconduct hearings.

Parallel Article III Civil Litigation. Another somewhat unusual feature of PTAB adjudication is that it is not the exclusive means of resolving the dispute between the private parties. That is, a third party who questions the validity of an issued patent can bring a challenge before the PTAB or file a declaratory judgment action in federal district court. Despite the popularity of PTAB adjudication, the validity of most patents is still challenged in patent infringement suits filed in federal court. ${ }^{160}$ Concurrent proceedings are also found within the trademark context: the validity of a trademark may be adjudicated before the TTAB or in federal court. ${ }^{161}$ These concurrent proceedings, however, are rare in the administrative state. Such parallel court proceedings do not exist in the public benefits context, where courts usually only get involved once there is a final agency action to review. ${ }^{162}$ Similarly, with

157. Id. at 836 (citing 7 U.S.C. $§ 18(1976)$ ).

158. Id. at 857.

159. See BARNETT ET AL., supra note 13, at 32-33.

160. Vishnubhakat et al., supra note 115, at 69.

161. Technically, the TTAB adjudicates the validity of the federal registration of a mark whereas the federal judiciary adjudicates the validity of a mark. However, there is substantial overlap between these requirements. See Melissa F. Wasserman, What Administrative Law Can Teach the Trademark System, 93 WASH. U. L. REV. 1511, 1521, 1524 (2016). Nevertheless, there are important differences between parallel proceedings in patent and trademark cases. Perhaps most saliently, unlike in trademark cases, there is almost no possibility of court-agency preclusion in patent cases due to differences in claim construction regimes and standards of proof, among other things. See Paul R. Gugliuzza, (In)valid Patents, 92 NOTRE DAME L. REV. 271, 287-92 (2016).

162. See 5 U.S.C. $\S 704$ (2012) ("Agency action made reviewable by statute and final agency action for which there is no other adequate remedy in a court are subject to judicial review. A preliminary, procedural, or intermediate agency action or ruling not directly reviewable is subject to review on the review of the final agency action.”). 
public enforcement actions, the agency generally must choose to resolve the issue either via agency adjudication or federal court. ${ }^{163}$ This feature of PTAB adjudication has already received substantial criticism, ${ }^{164}$ and it will no doubt continue to receive extensive scholarly attention.

Filing Fees. The third way in which PTAB adjudication differs from typical Type $\mathrm{B}$ adjudication is that the Patent Office has a unique power among federal agencies to collect and, after the AIA, even set fees for its various applications and adjudications, including PTAB adjudication. ${ }^{165}$ For instance, as of January 16,2018 , a request for inter partes review costs at least $\$ 15,000$, with additional fees for a variety of actions, including requesting an oral hearing $(\$ 1,300)$ and filing a notice of appeal $(\$ 800) .{ }^{166} \mathrm{We}$ are unaware of other agency adjudications where a private party must pay a fee to participate in the adjudication, much less where the agency itself has the authority to set that fee.

High-Volume Adjudication. Finally, unlike most private enforcement agency adjudications, PTAB adjudications involve much greater numbers of cases. As detailed in Part II, since 2012 the Patent Office has received over 7,000 post-grant petitions. To be sure, PTAB's caseload falls short of the tens or hundreds of thousands of cases which characterize mass agency adjudication, such as in the context of Social Security benefits, veterans' health, disability, and education benefits, and immigration matters. But, the PTAB is facing many of the same caseload management and consistency in adjudication challenges that have long plagued mass agency adjudication contexts. We explore these challenges, at least tangentially, in Part IV.

\section{The Final PTAB Departure: The Lack of Agency-Head Final Decision- Making Authority}

The final way in which the PTAB differs from typical Type B adjudication is that the Patent Office Director lacks final decision-making authority over PTAB decisions, although she can influence PTAB outcomes by designating APJs to the PTAB panel that she hopes share her views. As discussed in Part I, agency head control is a core feature of both the old and new world of agency adjudication. Notwithstanding the prevalence of agency-head review, little scholarly attention has been paid to its impact on the new world of agency adjudication. ${ }^{167}$

163. For a discussion of this adjudication and court choice in the SEC context, see, for example, Stephen J. Choi \& A.C. Pritchard, The SEC's Shift to Administrative Proceedings: An Empirical Assessment, 34 YALE J. ON REG. 1 (2017).

164. See Dolin, supra note 118, at 903-07; Gugliuzza, supra note 161, at 325-30.

165. See generally Jonathan S. Masur, CBA at the PTO, 65 DUKE L.J. 1701, 1707-22 (2016).

166. USPTO Fee Schedule, USPTO, https://www.uspto.gov/sites/default/files/documents/USPTO fee schedule_current.pdf [https://perma.cc/EY3Y-XQ6K] (last visited Dec. 22, 2018).

167. One major exception is immigration adjudication, wherein the Attorney General's final decision-making authority has received sustained scholarly attention. See, e.g., Joseph Landau, DOMA 
As discussed in Part I.B, ACUS has identified a handful of Type B adjudications where there is no agency-head final decision-making authority. ${ }^{168}$ In addition to the PTAB, two agencies out of Asimow's ten case studies - the Civilian Board of Contract Appeals and the Board of Veterans Affairs-lacked higher-level agency reconsideration of their decisions. ${ }^{169}$ Despite these exceptions, the majority of Type B adjudications are subject to agency head review, although some are first subject to an intermediate-level review before review by the agency head. ${ }^{170}$ Agency-head review typically comes in one of two flavors: mandatory and discretionary. Immigration adjudication, which is perhaps the predominant Type B adjudication in the modern administrative state, is discretionary. ${ }^{171}$

In immigration adjudication, removal proceedings for noncitizens are adjudicated before non-ALJ immigration judges, who are part of the Justice Department's Executive Office of Immigration Review. In fiscal year 2016,

and Presidential Discretion: Interpreting and Enforcing Federal Law, 81 FORDHAM L. REV. 619, 639 n.89 (2012); Peter J. Levinson, A Specialized Court for Immigration Hearings and Appeals, 56 NOTRE DAME L. REV. 644, 650 (1981); David A. Martin, Reforming Asylum Adjudication: On Navigating the Coast of Bohemia, 138 U. PA. L. REV. 1247, 1345 n.265 (1990); Margaret H. Taylor, Behind the Scenes of St. Cyr and Zadvydas: Making Policy in the Midst of Litigation, 16 GEO. IMMIGR. L.J. 271, 288 (2002); Laura S. Trice, Note, Adjudication by Fiat: The Need for Procedural Safeguards in Attorney General Review of Board of Immigration Appeals Decisions, 85 N.Y.U. L. REV. 1766, 1767 (2010). Most recently, the Iowa Law Review published a coauthored article on the subject by former US Attorney General and now Dean Alberto Gonzales, see Alberto R. Gonzales \& Patrick Glen, Advancing Executive Branch Immigration Policy Through the Attorney General's Review Authority, 101 IowA L. REV. 841 (2016), and a series of responses. See David A. Martin, Improving the Exercise of the Attorney General's Immigration Referral Power: Lessons from the Battle over the "Categorical Approach" to Classifying Crimes, 102 IOwA L. REV. ONLINE 1 (2016); Bijal Shah, The Attorney General's Disruptive Immigration Power, 102 IOWA L. REV. ONLINE 129 (2017); Margaret H. Taylor, Midnight Agency Administration: Attorney General Review of Board of Immigration Appeals Decisions, 102 IowA L. REV. ONLINE 18 (2016). One of us explored how courts can leverage the Attorney General's referral authority to engage in a richer dialogue with the agency on remand and to have a more systemic effect in adjudication. See Christopher J. Walker, Referral, Remand, and Dialogue in Administrative Law, 101 IOWA L. REV. ONLINE 84, 95 (2016).

168. See supra note 82 and accompanying text. Weaver also identifies the Labor Department's Wage Appeals Board (now Administrative Review Board) as another example of an adjudication where the agency head does not have final decision-making authority. See Weaver, supra note 46, at 260.

169. AsIMOW, supra note 65 , at 33 . Veterans' benefits adjudication is a peculiar agency adjudication model. Veterans file more than one million new claims per year, which regional offices of the Veterans Benefits Administration initially adjudicate. $I d$. at 84 . Claimants may then seek review within the agency at the Board of Veterans' Appeals, and the Board's decision is the final agency action. See Henderson ex rel. Henderson v. Shinseki, 562 U.S. 428, 431 (2011) ("[I]f a veteran is dissatisfied with the regional office's decision, the veteran may obtain de novo review by the Board of Veterans' Appeals. The Board is a body within the VA that makes the agency's final decision in cases appealed to it.” (citing 38 U.S.C. $\S \S 7101,7104($ a))). The next level of review, however, is not an Article III federal court, but an Article I legislative court - the United States Court of Appeals for Veterans Claims. See id. at 432 (citing 38 U.S.C. $\$ \S 7251,7252$ (a)). After this legislative court review, claimants may proceed to an Article III court - the Federal Circuit. See id. at 433 (citing 38 U.S.C. § 7292).

170. Asimow, supra note 65, at 33. See A Guide to FEDERAl AgENCY AdJUdicATION: SECTION OF ADMINISTRATIVE LAW AND REGULATORY PRACTICE OF AMERICAN BAR ASSOCIATION, at 88-89 (Michael Asimow ed., 2003).

171. See 8 C.F.R. § 1003.1(h) (2018). 
immigration courts received 328,112 matters and completed 273,390 matters. ${ }^{172}$ Immigration judge decisions can be administratively appealed by the noncitizen or the government to the Board of Immigration Appeals (BIA). The BIA chair divides the seventeen-member BIA into three-member panels to review immigration-judge decisions (though most cases are heard by one BIA member). ${ }^{173}$ In fiscal year 2016, the BIA received 30,200 cases and completed 33,240 cases. ${ }^{174}$

As is the case for virtually all Type A and Type B adjudications, the agency head - the Attorney General-has final decision-making authority over immigration adjudication, although it is discretionary. ${ }^{175}$ More specifically, one of three legal actors can refer a BIA case to the Attorney General: the Attorney General herself, the BIA (acting through its Chair or a majority of its members), or the Secretary of Homeland Security. ${ }^{176}$ The ultimate decision as to whether to accept the referral request lies with the Attorney General. ${ }^{177}$ Thus, the Attorney General only reviews cases on a discretionary basis. Given the workload demands on the BIA, it is unsurprising that her review authority is discretionary. Requiring the Attorney General to review every BIA decision would likely result in an overwhelming administrative burden on the Attorney General.

In contrast to the discretionary review associated with immigration adjudication, other Type B adjudications mandate agency-head review of their determinations. Agencies that guarantee an aggrieved party a right of appeal to the agency head, however, tend to have smaller adjudicative caseloads than the BIA or even the PTAB. For example, personnel security cases - also known as security clearance cases - are Type B adjudications in which the Department of Energy (DOE) or contractor employees challenge a decision that denied the employee access to classified materials. ${ }^{178}$ An aggrieved employee can elect a hearing before a non-ALJ administrative judge at the DOE. ${ }^{179}$ The employee can

172. U.S. DEP'T OF JUSTICE EXEC. OFFICE FOR IMMIGRATION REVIEW, FY 2016 STATISTICS YEARBOOK, at A2 fig.1 (2017) [hereinafter EOIR FY 2016 YEARBOOK], https://www.justice.gov/eoir/page/file/fysb16/download [https://perma.cc/D6HQ-V9SG]. As of June 2017, there were 326 immigration judges nationwide. Press Release, Department of Justice, Executive Office for Immigration Review Swears in 11 Immigration Judges (June 16, 2017), https://www.justice.gov/eoir/pr/executive-office-immigration-review-swears-11-immigration-judges [https://perma.cc/WPD4-JSPV]. Regulations established proceedings for immigration court, including notice requirements, entitlement to be represented by an attorney, in-person or videoconference hearing provisions, and rights to introduce evidence and cross-examine witnesses. See 8 C.F.R. $\S \S 1003.12-.47$ (2018); see also ASIMOW, supra note 65, at 61-66 (describing process).

173. See 8 C.F.R. $\S 1003.1$ (2018); see also AsIMOW, supra note 65, at 66-68 (describing process). Cases heard by a single BIA member are decided without oral argument and usually without a detailed, reasoned opinion. By definition, single-member BIA decisions should not be precedential as they merely apply existing law. See 8 C.F.R. § 1003.1(e)(4).

174. EOIR FY 2016 YEARBOOK, supra note 172, at Q2 fig. 27.

175. See 8 C.F.R. § 1003.1(h). See generally Gonzales \& Glen, supra note 167.

176. Id. $\S 1003.1(\mathrm{~h})(1)$.

177. See Walker, supra note 167 , at 84 .

178. 10 C.F.R. $\S 710$ (2018); see also AsIMOW, supra note 65, at 42-46 (describing the process).

179. 10 C.F.R. $§ 710.21$ (b) (2018). 
appeal an unfavorable decision to the three-member DOE Headquarter Appeals Panel. ${ }^{180}$ The aggrieved party can further appeal to the Secretary of Energy in limited scenarios. ${ }^{181}$ In contrast to immigration adjudication that processes hundreds of thousands of cases a year, in fiscal year 2014 the DOE adjudicated only 121 personnel security cases. ${ }^{182}$

Whether agency-head final decision-making authority is mandatory or discretionary, it remains a hallmark of Type A and Type B adjudication and is deeply rooted in the administrative state. Part IV explores the implications of the lack of agency-head final decision-making authority at the Patent Office.

IV.

\section{The IMPortance of AgENCY-HeAd FinAl DeCision-MAKING AUthority}

Part I demonstrated how the new world of agency adjudication diverges considerably from the APA-governed formal adjudication that dominates what students learn in the classroom. It then documented the emergence of Type B adjudication: agency adjudication with a statutory requirement of a written or oral hearing but that, nonetheless, technically falls outside the scope of APAgoverned formal adjudication. Finally, Part III situated PTAB adjudication within this new world, highlighting a number of ways in which PTAB adjudication differs from typical Type $\mathrm{B}$ adjudications.

This final Section explores the implications of this analysis, focusing on one key difference: the lack of agency-head final decision-making authority. Part IV.A starts by examining the concerns associated with the lack of appellate review structure within the Patent Office and argues that unique aspects of the Patent Office compound these disadvantages. Part IV.B examines the primary way in which the Patent Act provides the Director with control over the PTAB's outcomes: "stacking" the panel to help ensure the outcome aligns with the Director's policy preferences. After concluding that the Director's designation procedures are statutorily authorized by the Patent Act, this Section argues that the procedure raises a colorable due process violation. Part IV.C closes by surveying alternative mechanisms that would help remedy the Director of the Patent Office's lack of final decision-making authority and by detailing the new "precedential opinion panel" procedures the PTAB embraced in September 2018 to help address the lack of agency-head final decision-making authority.

180. Id. § 710.29.

181. See Personnel Security Hearing, Case No. PSH-14-0011 (Dep't of Energy June 19, 2014) (Administrative Judge Decision), http://energy.gov/sites/prod/files/2014/06/f16/PSH-14-0011.pdf [https://perma.cc/CTE6-ZVZR].

182. See AsIMOW, supra note 65 , at 42 . 


\section{A. Ramifications of the Lack of Agency-Head Final Decision-Making Authority}

As Part I illustrated, the traditional administrative model vests final decision-making authority with the agency head. In APA-governed formal adjudication, the APA stipulates that the ALJ's initial decision is not entitled to deference on administrative review. ${ }^{183}$ That is, an agency head maintains complete freedom, as though she had heard the initial evidence herself, when reviewing the decision of the ALJ. The same typically holds for Type B adjudications, although agency heads are normally reviewing decisions by nonALJ adjudicators. ${ }^{184}$

There are several reasons why the traditional administrative model vests final decision-making authority with the agency head. Perhaps most saliently, it ensures agency heads control the regulatory structure they supervise. Agency heads - who can comprise a single director, secretary, or administrator; or a commission, board, or body with five to seven members - oversee the agency's activities and set the agency's policy preferences. It is widely accepted that agency heads have a comparative advantage in policy expertise relative to agency adjudicators. ${ }^{185}$ Generally, agency leadership has greater access to experts and staff that provide inputs and partake in the deliberative process that lead to better informed decisions than adjudicatory officers. ${ }^{186}$ Moreover, in contrast to agency heads, adjudicatory officers often have significant caseloads that rob them of the time necessary to think deeply about policy matters. ${ }^{187}$ Because adjudication is a primary policy-making vehicle for federal agencies, granting agency-head review authority over adjudication helps to ensure agencyhead control over policy development. ${ }^{188}$

Although the literature to date is largely supportive of the traditional administrative model, there are a few detractors. ${ }^{189}$ Opponents of agency heads having final decision-making authority over adjudication argue that the need for such agency-head review varies across agencies. These commentators often point out that a number of agencies with the traditional adjudicatory structure have agency heads that either rarely invoke review authority or have delegated the authority to independent subordinates. ${ }^{190}$ Of course, the frequency at which an agency head evokes her review authority does not necessarily reveal how important this power is to policing the consistent application of agency policy

183. FCC v. Allentown Broad. Corp., 349 U.S. 358, 364-65 (1955)

184. See supra Part I.B.

185. VERKUIL, supra note 74.

186. Id.

187. Id.

188. See Magill, supra note 9, at 1386.

189. Levin, supra note 7 , at 413 \& n.36 (noting "[m]odels in which administrative judges' decisions may not be reviewed by agency heads have been widely criticized in scholarly literature").

190. See Weaver, supra note 46, at 287-88; see also Shah, supra note 167; Taylor, supra note 167. 
preferences. Even if it is infrequently evoked, such authority may still play a disproportionate role in the agency head's supervisory authority. ${ }^{191}$ Moreover, even when the agency head has relinquished review authority to subordinates, the agency head still maintains ultimate control. If the agency head dislikes the reviewer's decisions, she can remove the reviewer and appoint someone elsealthough, as discussed above, the removal may have to occur at the end of the proceeding. ${ }^{192}$

Additionally, particular features of the Patent Office suggest an even greater need for the Director to have final decision-making authority than other agency heads. Most importantly, the Patent Office lacks one of the primary vehicles agencies use to make policy: a broad grant of substantive rulemaking authority. ${ }^{193}$ Because rulemaking and adjudication are at least partial substitutes for agency policy-making, the Patent Office disproportionately relies on the process of adjudication (at least with respect to most agencies that possess both policy-making vehicles) to address novel legal issues that implicate policy choices. ${ }^{194}$ Given the agency's skewed reliance on adjudication to make policy, the lack of direct agency-head review is even more concerning.

A second reason agency heads possess direct review of adjudications is to help ensure consistency in adjudicative outcomes. In his seminal book Bureaucratic Justice, Jerry Mashaw grounded his theory of agency adjudication in "bureaucratic rationality," which values consistency and accuracy in adjudicative outcomes achieved via agency-head control and policy-making. ${ }^{195}$ From a normative perspective, consistency in adjudicatory outcomes is important to fairness arguments underlying equal enforcement, as well as encouraging confidence and hence ex ante compliance with agency policy. ${ }^{196}$ Unfortunately, inconsistent decisions are a reality of the adjudicative process. Agency heads often try to limit the discretion of their staff through the

191. See, e.g., Gonzales \& Glen, supra note 167.

192. See generally Jennifer Nou, Subdelegating Powers, 117 ColuM. L. REV. 473 (2017) (further categorizing and theorizing the phenomenon of agency subdelegation of various powers).

193. Merck \& Co., Inc. v. Kessler, 80 F.3d 1543, 1549-50 (Fed. Cir. 1996) (noting that the Patent Office lacks the ability to promulgate rules on the core patentability standards that carry the force of law).

194. Magill, supra note 9, at 1398. There are exceptions, such as the National Labor Relations Board (NLRB), which possess broad rulemaking authority but nonetheless choose to formulate policy primarily through adjudication. See Mark H. Grunewald, The NLRB's First Rulemaking: An Exercise in Pragmatism, 41 DUKE L.J. 274, 274 (1991) ("Despite having been granted both rulemaking and adjudicatory power in its statutory charter more than half a century ago, the [NLRB] has chosen to formulate policy almost exclusively through the process of adjudication.").

195. JERry L. MASHAW, BurEAUCRATIC Justice: MANAGING SOCIAL SECURITY BENEFITS Claims 25-26 (1983); Robert A. Kagan, Inside Administrative Law, 84 ColuM. L. REV. 816, 820 (1984) (detailing how Mashaw's "bureaucratic rationality" is a model of agency adjudication that facilitates " $[\mathrm{g}]$ reater control and consistency" by placing the "overriding value" on "accurate, efficient and consistent implementation of centrally-formulated policies"); see also Hoffer \& Walker, supra note 24, at 276-89 (exploring the importance of consistency, efficiency, and equity in agency adjudication).

196. See, e.g., Hoffer \& Walker, supra note 24, at 278. 
promulgation of guidelines, regulations, and manuals that agency officials must follow. ${ }^{197}$ Nevertheless, agency adjudicators often retain substantial discretion in their decision-making for a number of reasons, including the inability of an agency head to delineate every circumstance an adjudicatory official will face. As a result, agency-head review of adjudicatory outcomes helps ensure that agency policy preferences are consistently applied and that similarly situated parties receive similar results across decision-makers.

Consistency is especially pressing for an agency like the Patent Office, which makes a relatively high volume of determinations each year on comparatively complex subject matters. The PTAB, which comprises close to 300 APJs, has been criticized for issuing inconsistent decisions. ${ }^{198}$ Moreover, the complex scientific inquiries associated with determining the validity of a patent only increase the risk that different PTAB panels may render different determinations. As a result, the lack of agency-head review of PTAB adjudications also frustrates the Director's ability to bring consistency to its adjudicatory body's outcomes or ensure similarly situated parties receive similar results across PTAB panels.

A final benefit is, as Russell Weaver puts it, that agency-head review "helps the agency head gain greater awareness of how a regulatory system is functioning." 199 Such awareness does not just assist the agency head in tailoring training and instruction for the agency's adjudicators. It also helps the agency head consider whether adjustments to the regulatory scheme are necessary via rulemaking, precedential adjudication, agency guidance, legislative recourse, or other means. Such agency-head awareness is even more critical with respect to agencies that have substantial enforcement or similar regulatory responsibilities.

This benefit is quite significant to the Patent Office. The Patent Office employs more than 8,000 patent examiners that process over 600,000 patent applications per year. ${ }^{200}$ As one of us has explored in a series of papers, the quality and consistency of patent examination varies widely, and effective training can play a significant role in improving agency adjudication at the

197. JoHn BREHM \& SCOTT GATES, WorkING, SHIRKING, AND SABOtAGE: BuREAUCRATIC Response IN A Democratic Republic 21 (1999); Mark Seidenfeld, Why Agencies Act: A Reassessment of the Ossification Critique of Judicial Review, 70 OHIO ST. L.J. 251, 280 (2009).

198. Stuart Minor Benjamin \& Arti K. Rai, Administrative Power in the Era of Patent Stare Decisis, 65 DUKE L.J. 1563, 1589 (2016) (noting "complaints by the patent bar that PTAB panel opinions on a number of issues are inconsistent"). Notably, this occurs even though each PTAB panel comprises multiple judges. A multi-judge panel helps to limit an outlier adjudicator's ability to skew agency decision-making.

199. Weaver, supra note 46, at 289.

200. U.S. PATENT AND TRADEMARK OFFICE, PERFORMANCE AND ACCOUNTABILITY REPORT:

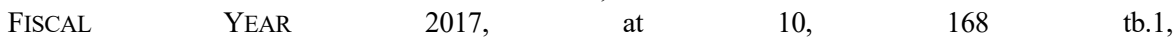
https://www.uspto.gov/sites/default/files/documents/USPTOFY17PAR.pdf [https://perma.cc/A4A8U6QT] (last visited Dec. 21, 2018). 
patent-issuing level. ${ }^{201}$ The better the Director understands how the regulatory system is functioning, the better positioned she is to address systemic issues through further guidance and training. Final decision-making authority of PTAB decisions would aid on that front. Indeed, she can help provide that guidance through her precedential decisions on rehearing of PTAB adjudications.

In sum, if the Director of the Patent Office had final decision-making authority over PTAB adjudication, she would be able to more effectively exercise policy control over PTAB adjudication, bring greater consistency to PTAB adjudications, and better understand how the Patent Office's regulatory system is functioning. These benefits would extend beyond improving PTAB adjudication to also assist the agency in examining patents in the first place.

\section{B. The Director's Authority to "Stack" PTAB Panels}

Although the PTAB lacks appellate review and agency-head final decisionmaking authority, the Director can influence PTAB outcomes. The Patent Act enables the Director to designate members of the PTAB for any particular case and vests exclusive authority to grant a rehearing to the PTAB. ${ }^{202}$ The Director has utilized this ability to designate like-minded members to a panel-i.e., to "stack" the panel - to ensure PTAB outcomes consistently align with her desired policy preferences. ${ }^{203}$

Perhaps the most famous example of the Director's ability to influence the Patent Office's adjudicatory tribunal's outcomes is In re Alappat. ${ }^{204}$ In Alappat, a three-member panel of PTAB's predecessor reversed the patent examiner's pending rejection of claims; the patent examiner had found that the claims should

201. See Michael D. Frakes \& Melissa F. Wasserman, Patent Office Cohorts, 65 DuKE L.J. 1601 (2016); Frakes \& Wasserman, Does the U.S. Patent \& Trademark Office Grant Too Many Bad Patents?, supra note 86; Michael D. Frakes \& Melissa F. Wasserman, Does Agency Funding Affect Decisionmaking?: An Empirical Assessment of the PTO's Granting Patterns, 66 VAND. L. REV. 67 (2013).

202. 35 U.S.C. $\S 6(\mathrm{c})$ (2012). It is worth noting that, in the immigration adjudication context, the head of the Board of Immigration Appeals - not the Attorney General herself- "may from time to time make changes in the composition of such panels and of presiding members." 8 C.F.R. $\S 1003.1(a)(3)$ (2018). We are not aware of any instance in which the BIA chair has exercised this authority to stack a panel to reach a particular outcome, though the Attorney General has historically used her separate final decision-making authority to overrule BIA decisions and impose different policy outcomes. See supra note 167 and accompanying text.

203. This ability has led at least one commentator to note that the Director of the Patent Office "retains formal control" over the Board. See, e.g., Daniel J. Gifford, Adjudication in Independent Tribunals: The Role of an Alternative Agency Structure, 66 NOTRE DAME L. REV. 965, 983 (1991). This article was referring to BPAI, the predecessor of PTAB, but the AIA utilizes the same language regarding the designation of Board members.

204. 23 U.S.P.Q.2d (BNA) 1340 (B.P.A.I. 1991), rev'd, 33 F.3d 1526 (Fed. Cir. 1994). When In re Alappat was decided, the Director of the Patent Office was referred to as the Commissioner. See American Inventors Protection Act of 1999, Pub. L. No. 106-113, sec. 4713, §3(a)(1), 113 Stat. at 1501A-575-578 (codified as amended at 35 U.S.C. § 3(a)(1) (2012)) (elevating the position of head of the Patent Office from Commissioner to Director). 
be rejected as they were directed to non-statutory subject matter. ${ }^{205}$ The examiner requested reconsideration on the basis that the "panel's decision conflicted with [Patent Office] policy" and "that such reconsideration be carried out by an expanded panel." ${ }^{206}$ An expanded eight-member panel of the Patent Office's adjudicatory board consisting of the three original members and five highranking officials of the Patent Office evaluated the request for reconsideration. ${ }^{207}$ The majority of the expanded panel, consisting of the newly appointed panel members appointed by the Director, issued a new opinion in which they affirmed the patent examiner's patentable subject matter rejection. The three original panel members dissented on the merits for the reasons set forth in their original opinion. $^{208}$

A more recent example is Nidec Motor Corp. v. Zhongshan Broad Ocean Motor Co. ${ }^{209}$ The Nidec case involved the issue of joining two petitions from the same petitioning party when there were arguably conflicting PTAB decisions on joinder practices. ${ }^{210}$ Similar to Alappat, the underlying case was initially decided by a three-member PTAB panel. ${ }^{211}$ In a split decision, the panel held the joining was improper, and Broad Ocean requested rehearing and expanded-panel consideration. ${ }^{212}$ An expanded five-member panel issued a new opinion in which the majority - comprised of the new panel members and the original dissenting judge - held the joining was proper. ${ }^{213}$

Moreover, agency leadership, at times, has found it necessary to utilize multiple rounds of expanded panels to ensure that PTAB decisions conform to the agency's policy preferences. Consider, for example, Target Corp. v. Destination Maternity Corp., another recent case that involved the PTAB's joinder practices. ${ }^{214}$ The initial panel consisted of three APJs. ${ }^{215}$ Two additional administrative judges joined the panel prior to an initial decision. ${ }^{216}$ The

205. 33 F.3d at 1546 .

206. Id. at 1531.

207. Id.

208. Id. at 1576 .

209. 868 F.3d 1013 (Fed. Cir. 2017).

210. Id. Compare Target Corp. v. Destination Maternity Corp. IPR 2014-00508, Paper 18 (P.T.A.B. Sept. 25, 2014) (denying the joining of two petitions of a same petitioning party under 35 U.S.C. § 315(c) as a matter of law), with Microsoft Corp. v. Proxyconn, Inc. IPR 2012-00026, Paper 17 (P.T.A.B. Dec. 21, 2012) (permitting the joining of two petitions of the same petitioning party under 35 U.S.C. $\S 314(\mathrm{c})$ as a matter of law).

211. Nidec, 868 F.3d at 1015.

212. Id.

213. Id.

214. Target Corp. v. Destination Maternity Corp., No. IPR 2014-00508, Paper 18 (P.T.A.B. Sept. $25,2014)$.

215. See Order on the Conduct of the Proceeding, Target Corp. v. Destination Maternity Corp., No. IPR 2014-00508, Paper 4 (P.T.A.B. Mar. 25, 2014).

216. Target Corp. v. Destination Maternity Corp., No. IPR 2014-00508, Paper 18 (P.T.A.B. Sept. 25, 2014). PTAB Standard Operating Procedures allow for an expanded panel to be granted before the initial decision is issued. PATENT TRIAL AND APPEAL BD., STANDARD OPERATING PROCEDURE 1 (REVISION 14): AssignMent OF JUdGes TO MERITS PANELS, INTERLOCUTORY PANELS, AND 
expanded five-judge panel did not rule the way the Director had hoped. In a 3-2 decision, with the two added judges dissenting, the panel denied joinder. ${ }^{217}$ The agency granted a request for rehearing and expanded the panel a second time, adding two more APJs to bring the total number to seven. ${ }^{218}$ The twice-expanded panel issued a 4-3 decision allowing joinder. The four added APJs were in the majority. ${ }^{219}$

Enlarging the PTAB panel upon rehearing raises at least two legal questions. First, does the Director have the statutory authority to expand the panel and rehear a case after the original panel issues its decision? Second, does the expanded panel, consisting of individuals the Director has appointed in hopes of reversing the initial three-judge panel, offend constitutional due process principles?

\section{Statutory Authority Challenge}

The legal controversy associated with the Director's authority to stack panels primarily stems from rehearings. That is, can the Director handpick members to create an expanded panel after the initial decision has been rendered with the hope that the expanded panel will grant the rehearing and reverse? The answer seems to be yes.

The Patent Act defines the overall membership of the PTAB: "The Director, the Deputy Director, the Commissioner for Patents, the Commissioner for Trademarks, and the administrative patent judges shall constitute the Patent Trial and Appeal Board." 220 The Patent Act also enables the Director to designate the members who shall constitute the PTAB for any given case: "Each . . . postgrant review, and inter partes review shall be heard by at least 3 members of the Patent Trial and Appeal Board, who shall be designated by the Director."221 However, with respect to rehearings, the Patent Act provides that "[o]nly the Patent Trial and Appeal Board may grant rehearings." ${ }^{, 22}$

Notably, the Patent Act is silent on who may act as the PTAB to rehear the case. If the term PTAB means all members of PTAB acting as a collective unit or only the original panel members who heard the initial hearing, then the Director's designation practices would violate the Patent Act. If, however, the term PTAB included an expanded panel hand-picked by the Director, then the

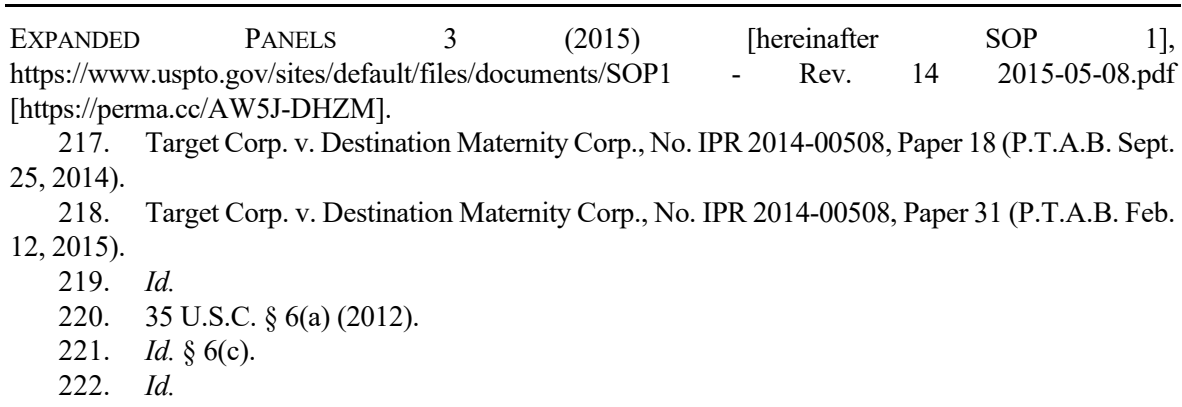


Patent Act would authorize the Director's designation procedures. The Patent Act's vague language regarding rehearings does not appear to compel or prohibit any of these interpretations. Hence, the term PTAB appears to be ambiguous.

The Patent Act grants the Director broad administrative powers, including the ability to promulgate regulations governing inter partes and post-grant review. ${ }^{223}$ As a result, under standard administrative law principles, this grant of rulemaking authority gives the agency leeway to enact reasonable rules given the ambiguous terms of the Patent Act and the text, nature, and purpose of the statute. ${ }^{24}$ The agency's interpretation to include an expanded panel is reasonable, because no statutory provision unambiguously mandates who comprises the PTAB to grant a rehearing. Thus, under the deference framework outlined in Chevron v. Natural Resources Defense Council, ${ }^{225}$ the Director's designation procedures, at least if promulgated in a final rule, comply with the Patent Act. ${ }^{226}$ That "[t]he Director shall be responsible for providing policy direction and management supervision for the Office and for the issuance of patents" provides further evidence that the agency's interpretation is reasonable and permissible. 227

The Federal Circuit held that the Director's expanded panel practices did not constitute a clear violation of the Patent Act in In re Alappat, ${ }^{228}$ which involved an adjudicatory body that preceded the PTAB. But, such reasoning should apply with the same force to the PTAB. ${ }^{229}$ Although the Federal Circuit

223. Id. $\S \S 2,6$.

224. United States v. Mead Corp., 533 U.S. 218, 229 (2001).

225. Chevron U.S.A. Inc. v. Nat. Res. Def. Council, Inc., 467 U.S. 837, 844 (1984) (instructing courts to defer to an agency's reasonable interpretation of an ambiguous statute that the agency administers).

226. The legislative history supports giving the Director broad discretion to define who may act as the Board to rehear a case. Ironically, the concepts of rehearings and including the Director and other high ranking officials as members of the Board were added to the Patent Act in 1927, when Congress decided to eliminate the right to appeal adverse Board decisions directly to the Director of the Patent Office. Because the Director could not keep up with the number of appeals, appellate review was removed and rehearing authority vested with the Board. See infra notes 270-271 and accompanying text. Nevertheless, the legislative history of the 1927 Act indicated that "the supervisory power of the Commissioner, as it has existed for a number of decades, remains unchanged." In re Alappat, 33 F.3d 1526, 1550 (Fed. Cir. 1994) (emphasis added) (citing S. Rep. No. 1313, 69th Cong., 2d Sess. 4 (1927)).

227. 35 U.S.C. $\S 3(\mathrm{a})(2)(\mathrm{A})(2012)$.

228. Alappat, 33 F.3d 1526. A plurality concluded that the Patent Act authorized the Director's designation procedures, while three other judges found the Director's designation practices did not constitute a clear violation of the Patent Act. Subsequent to Alappat, the Director delegated to the Chief Judge of PTAB the power to order rehearing before an expanded panel and to select who sits on those panels. SOP 1, supra note 216, at 2. The Patent Office has also provided more guidance as to when an expanded panel should be utilized and what may drive the selection of additional panel members. The PTAB's Standard Operating Procedures suggests that expanded panels should be utilized when, among other things, a proceeding "involves an issue of exceptional importance" or is "necessary to secure and maintain uniformity of the Board's decisions," $i d$. at 3, and directs the Chief Judge to consider "technical or legal expertise" when choosing additional panel members. Id. at 4.

229. The near-identical language in the Patent Act associated with convening panels of BPAI and PTAB suggests that Alappat's reasoning would apply to PTAB as well. Compare 35 U.S.C. $\S 6$ (b) 
did not explicitly adopt a deference framework for its analysis, the majority did find that the text, nature, and legislative history supported the Patent Office's interpretation that an expanded panel has the authority to grant a rehearing and decide the case. ${ }^{230}$

\section{Constitutional Due Process Concerns}

Given that the Director's designation procedures are consistent with the Patent Act, does the Director's selection of panel members based on their willingness to vote a certain way deprive an aggrieved party of due process? Unlike the statutory authority question, no court has considered whether the Director's designation procedures violate due process. ${ }^{231}$

Patents appear to constitute the type of property that is protected by the Fifth Amendment Due Process Clause. The Patent Act mandates that "if on ... examination it appears that the applicant [for a patent] is entitled to a patent under the law, the Director shall issue a patent therefor." ${ }^{232}$ Given that courts recognize due process protection for statutory entitlements, it is unsurprising that the Federal Circuit has applied due process requirements to the invalidation of patents in post-issuance proceedings. ${ }^{233}$

Due process guarantees "an impartial and disinterested tribunal," ${ }^{234}$ which applies to the adjudicative bodies of agencies and to courts. ${ }^{235}$ Nevertheless, courts have recognized that the blend of investigative and adjudicative functions often found in administrative agencies requires a more relaxed approach as to what qualifies as an "impartial" decision-maker in an agency's adjudicative body

(2012) ("Each appeal and interference shall be heard by at least three members of the Board of Appeals and Interferences, who shall be designated by the Commissioner. Only the Board of Patent Appeals and Interferences has the authority to grant rehearings."), with 35 U.S.C. § 6(c) (2012) ("Each appeal, derivation proceeding, post-grant review, and inter partes review shall be heard by at least three members of the Patent Trial and Appeal Board, who shall be designated by the Director. Only the Patent Trial and Appeal Board may grant rehearings.").

230. Alappat, 33 F.3d at $1551-52$.

231. The Federal Circuit declined to address whether the Director's designation practices of Board members violated due process in Alappat, 33 F.3d at 1536.

232. 35 U.S.C. $\S 131$ (2012).

233. See Patlex Corp. v. Mossinghoff, 758 F.2d 594, 598-99 (Fed. Cir. 1985) (holding that "[i]t is beyond reasonable debate that patents are property" protected by the Fifth Amendment's Due Process Clause). The Federal Circuit has also found that due process requirements apply to pre-issuance examination of patents. In re Baxter, 656 F.2d 679, 687 (Fed. Cir. 1981) (finding a "clear infringement of Baxter's procedural due process rights" in the Patent Office's rejection of claims).

234. Marshall v. Jerrico, Inc., 446 U.S. 242, 247-49 (1980).

235. Withrow v. Larkin, 421 U.S. 35, 46-47 (1975). 
than in a federal court. ${ }^{236} \mathrm{~A}$ violation of due process does not require proof of actual impartiality but instead only "an unconstitutional 'potential for bias." 237

When considering the impartiality of administrative tribunals, courts have focused on when a decision-maker's prior involvement or financial interest in a case will compromise neutrality, violating due process. ${ }^{238}$ In contrast, case law on permissible agency-head designation procedures is relatively sparse.

One exception is the Sixth Circuit's opinion in Utica Packing Co. v. Block. ${ }^{239}$ In Utica, the USDA brought a complaint concerning meat inspection services from Utica Packing Company before an ALJ who decided against Utica. ${ }^{240}$ Utica appealed the ALJ's decision within the USDA, and on appeal the judicial officer affirmed. ${ }^{241}$ After the Sixth Circuit reversed and remanded the case back to the agency, the judicial officer reluctantly dismissed the case. ${ }^{242}$ The judicial officer was then removed from the case by the Secretary of Agriculture - who "violently disagreed" with his decision — and was replaced by someone who had no legal or scientific background to hear the case. ${ }^{243}$ A petition for reconsideration was subsequently presented to the new judicial officer who ruled against Utica. ${ }^{244}$

On appeal, the Sixth Circuit found that the Secretary's replacement of the judicial officer violated due process. ${ }^{245}$ The court refused to accept the argument

236. Id.; see also id. at 47 ("The contention that the combination of investigative and adjudicative functions necessarily creates an unconstitutional risk of bias in administrative adjudication has a much more difficult burden of persuasion to carry. It must overcome a presumption of honesty and integrity in those serving as adjudicators; and it must convince that, under a realistic appraisal of psychological tendencies and human weakness, conferring investigative and adjudicative powers on the same individuals poses such a risk of actual bias or prejudgment that the practice must be forbidden if the guarantee of due process is to be adequately implemented.")

237. Caperton v. A.T. Massey Coal Co., 556 U.S. 868, 881 (2009) ("The inquiry is an objective one. The Court asks not whether the judge is actually, subjectively biased, but whether the average judge in his position is 'likely' to be neutral, or whether there is an unconstitutional 'potential for bias."'); see also Barnett, supra note 58, at 1672 ("Because of the difficulty in determining an adjudicator's subjective state of mind, due process mostly concerns itself with appearances of partiality.").

238. The Supreme Court's inquiry, however, has been rather limited. Consider, for instance, Schweiker v. McClure, 456 U.S. 188 (1982), the Court's leading decision in this area. The Schweiker Court considered whether administrative judges appointed by insurance carriers to review denials of Medicare payments by the carriers themselves were, "for reasons of psychology, institutional loyalty, or carrier coercion ... reluctant to differ with carrier determinations." Id. at 196 n.10. The Court found that the administrative judge's connection to insurers alone was not meaningful because the federal government, not the carriers, paid the claims and the administrative judge's salaries. The Court held that the presumption of an adjudicator's impartiality had not been overcome because "generalized assumptions of possible interest" were insufficient. $I d$ at 196.

239. Utica Packing Co. v. Block, 781 F.2d 71 (6th Cir. 1986).

240. Id. at $73-74$.

241. Id. at 74

242. Id.

243. Id. The Secretary also assigned a new legal advisor whose immediate supervisor had participated in the removal of the original Judicial Officer and "supervised the division responsible for the prosecution of Utica." Id.

244. Id. at 74-75.

245. Id. at 78 . 
that the Secretary, having delegated to the judicial officer the original authority to resolve certain matters, could reappropriate that power at will based on disagreement with the judicial officer's conclusions. ${ }^{246}$ Instead, the court held, "[t]here is no guarantee of fairness when the one who appoints a judge has the power to remove the judge before the end of proceedings for rendering a decision which displeases the appointer." ${ }^{247}$ The court concluded: "All notions of judicial impartiality would be abandoned if such a procedure were permitted." 248

It is important to note the unusual nature of the adjudicative scheme at issue in Utica. Under statutory authority, the Secretary had delegated final decisionmaking authority over these types of USDA adjudications to the judicial officer. ${ }^{249}$ In other words, the Secretary originally had final decision-making authority under the statute. Therefore, the Secretary could have reached the substantive conclusion achieved by removing the judicial officer but for subdelegating by regulation such final decision-making authority to the judicial officer. The Sixth Circuit's finding of a due process violation thus turned on the Secretary's voluntary delegation of final authority to another agency official, such that "the Secretary's efforts to change the result by the methods described in this opinion cannot be permitted to succeed." 250

Under the reasoning set forth in Utica, there is at least a colorable argument that the Director's designation procedures raise substantial due process concerns. "Because the neutrality of a panel selected to produce a particular result might be questioned," John Golden has argued, "constitutional constraints of due process ... might limit that directorial power over rehearings so that this power is in fact narrower than the statute facially allows. ${ }^{.251}$ Similar to the Secretary of Agriculture in Utica, the Director of the Patent Office effectively removes the original panel before the end of the proceedings when she designates an expanded panel that she hopes will arrive at a different substantive outcome. Although the Director does not technically replace any judge, the practical effect of adding a sufficient number of new members to reverse the original panel decision is functionally equivalent to the Secretary of Agriculture's removal of the judicial officer in Utica.

Indeed, in some ways, the Director's panel-stacking antics are more procedurally offensive than the Secretary's "manipulation of a judicial, or quasijudicial, system" in Utica. ${ }^{252}$ After all, at least Congress had vested final

246. Id. at 79 .

247. Id. at 78

248. Id.

249. Id. at 72 (citing 7 C.F.R. $\S 2.35$ (1985)).

250. Id. at 79 .

251. John M. Golden, Working Without Chevron: The PTO as Prime Mover, 65 DUKE L.J. 1657, 1663-64 (2016). But see Benjamin \& Rai, supra note 198, at 1588 ("“W]e are skeptical that interpreting the statute to give the agency head the effective ability to review decisions poses a due process concern.").

252. Utica, 781 F.2d at 78 . 
decision-making authority in the Secretary, and the Secretary had merely delegated that authority via regulation to a judicial officer. By contrast, the AIA did not grant any final decision-making authority to the Director, such that her manipulation of the agency's processes to secure a different outcome seems even less fair to the losing party's rights. Therefore, it seems reasonable to conclude that Utica would compel the same result in the PTAB context, at least in the Sixth Circuit where Utica remains binding precedent.

That said, it does seem counterintuitive to conclude that it offends constitutional due process for the head of an agency to impose her policy preference when the "standard federal model" for agency adjudication contemplates that the head of the agency has final decision-making authority. ${ }^{253}$ Indeed, the APA expressly contemplates de novo agency-head review of ALJ decisions for APA-governed formal adjudications, ${ }^{254}$ and the vast majority of Type B adjudications also provide for agency-head review. ${ }^{255}$ This standard federal model embraces the principle that agency adjudication should ultimately be controlled by a political appointee who can help shape agency policy via adjudication and has at least some degree of political accountability.

So why are there no constitutional concerns raised when an agency head reverses an ALJ's decision? In many ways, the Director's ability to stack a panel with like-minded members is functionally equivalent to an agency head's ability to reverse an ALJ's decision on factual or legal determinations. If the Director is unhappy with the initial PTAB decision, she can expand the panel to help ensure that the adjudicatory board's decision aligns with her policy preferences just as an agency head who is unhappy with an ALJ's decision can reverse the decision on appellate review. In both scenarios, there is an initial decision (by either a three-judge panel or an ALJ) and a second opinion that reverses (by an expanded panel or an agency head) that delineates the reasons for the reversal, including the policy preferences of the agency.

One answer may be that, unlike the traditional appellate review model, the PTAB's expanded panel model arguably strips the adjudicatory board of its impartial nature and runs afoul of the requirement that the decisional function in administrative adjudication "cannot be performed by one who has not considered evidence or argument. . . The one who decides must hear. ${ }^{~} 256$ While it is true that individual PTAB members decide the case without agency leadership directing APJs to vote a certain way, the ability of the Director to stack the panel to ensure the outcome of the PTAB decision as a whole is arguably predetermined and hence impartial. Put differently, because the expanded panel members are selected to reverse the original three-member decision, outcomes

253. Levin, supra note 7, at 412.

254. See 5 U.S.C. § 557(b) (2012); see also supra Part I.A.

255. See supra Part I.B.

256. Morgan v. United States, 298 U.S. 468, 481 (1936). 
are improperly put before the consideration of evidence and argument. ${ }^{257}$ This theory, to be sure, stretches constitutional due process beyond existing precedent and could arguably be invoked whenever an agency head reverses an ALJ.

Alternatively, the answer could lie in the fact that Congress expressly grants final decision-making authority to agency heads in most agency adjudication contexts, but it has not done so in the PTAB context (and in Utica, the Secretary had delegated away that authority by regulation). ${ }^{258}$ It would be odd for constitutional due process to turn on the scope of statutory authority granted to an agency. After all, Congress cannot cure a constitutional due process violation by granting the agency authority to violate the Constitution. Yet, it nevertheless seems grossly unfair for an agency official who lacks substantive authority to gain such authority by rigging the adjudicative process. That type of procedural concern seemed to be motivating the Sixth Circuit in Utica.

Even if the Director's panel-stacking practice falls short of an actual due process violation, Congress's decision not to grant the Director final decisionmaking authority may still limit the Director's ability to engage in panel-stacking on rehearing to secure a desired outcome that is contrary to the original panel's determination. After all, if a statute is susceptible to more than one reasonable interpretation, the modern doctrine of constitutional avoidance commands courts to construe the statute to avoid an interpretation that raises serious constitutional questions - even if the interpretation at issue is not actually unconstitutional. ${ }^{259}$ The existence of serious constitutional questions is sufficient to eliminate a plausible interpretation. That is because the canon of constitutional avoidance "is not a method of adjudicating constitutional questions by other means," but instead "a tool for choosing between competing plausible interpretations of a statutory text, resting on the reasonable presumption that Congress did not intend

257. This due process theory would also implicate agency leadership's designation of the original three-member panel. Designating the original three panel members appears to be well within the powers granted to the Director by the Patent Act. While agency officials deny that any three-member panels are hand selected by the Director, there would be no way of knowing if this occurs and, if it does, how frequently.

258. In light of the fact that the Director lacks statutory final decision-making authority over PTAB decisions, perhaps the Director's use of panel stacking to effectively obtain final decision-making authority violates the APA. After all, the APA commands courts to invalidate agency actions that are, inter alia, "arbitrary, capricious, an abuse of discretion, or otherwise not in accordance with law," or "in excess of statutory jurisdiction, authority, or limitations." 5 U.S.C. $§ 706(2)(A)-(C)$ (2012). The problem with such an APA argument is that, as discussed supra in Part IV.B.1, the Director's panelstacking and rehearing practices seem quite consistent with the Patent Act, as amended by the AIA.

259. See, e.g., Jones v. United States, 526 U.S. 227, 239 (1999) ("“W]here a statute is susceptible of two constructions, by one of which grave and doubtful constitutional questions arise and by the other of which such questions are avoided, [a court's] duty is to adopt the latter." (quoting United States ex rel. Attorney Gen. v. Del. \& Hudson Co., 213 U.S. 366, 408 (1909))); Edward J. DeBartolo Corp. v. Fla. Gulf Coast Bldg. \& Constr. Trades Council, 485 U.S. 568, 575 (1988) ("[W]here an otherwise acceptable construction of a statute would raise serious constitutional problems, the Court will construe the statute to avoid such problems unless such construction is plainly contrary to the intent of Congress." (citing NLRB v. Catholic Bishop of Chi., 440 U.S. 490, 499-501, 504 (1979))). 
the alternative which raises serious constitutional doubts." ${ }^{260}$ Although the Supreme Court has not been consistent in its approach, it has on occasion held that constitutional avoidance trumps Chevron deference, such that an agency cannot advance an otherwise reasonable interpretation of a statute if such interpretation raises serious constitutional questions. ${ }^{261}$

As detailed in Part IV.B.1, the Patent Act says nothing about who may act as the PTAB that votes to rehear a case. The Director has interpreted her statutory authority to designate the members of a PTAB panel ${ }^{262}$ to include the ability to add members to an existing panel after the panel's initial decision. The Director does this in order to have enough votes on the panel to grant rehearing and then reach a different substantive outcome. We concluded in Part IV.B.1 that the Director's position is permissible in light of the Patent Act's text, structure, and purpose. Indeed, the legislative history seems to confirm the Director's position. ${ }^{263}$ But if the Director's position nevertheless raises serious constitutional questions, a court may read the statute to prohibit the Director's interpretation. Indeed, as noted in the Introduction, at last year's oral argument in Oil States, Chief Justice Roberts raised due process concerns with respect to the Patent Office Director's panel-stacking and rehearing procedures. ${ }^{264}$

To avoid constitutional due process concerns, perhaps the Patent Act's grant of authority to the Director to designate panel members should be limited so as to prohibit strategic panel-stacking. That could include requiring that the rehearing vote is limited to the original three-judge panel or, conversely, include the whole PTAB membership. In sum, even if one is not fully persuaded that the Director's approach to panel-stacking offends due process, the Director's approach could be precluded by the existence of serious constitutional questions as to the agency's statutory interpretation. ${ }^{265}$

260. Clark v. Martinez, 543 U.S. 371, 381 (2005).

261. See, e.g., DeBartolo, 485 U.S. at 577 ("Even if [the agency's] construction of the Act were thought to be a permissible one, we are quite sure that in light of the traditional rule followed in Catholic Bishop, we must independently inquire whether there is another interpretation, not raising these serious constitutional concerns, that may fairly be ascribed to [the Act].”); see generally Christopher J. Walker, Avoiding Normative Canons in the Review of Administrative Interpretations of Law: A Brand X Doctrine of Constitutional Avoidance, 64 ADMIN. L. REV. 139, 144 (2012) (exploring the interaction between constitutional avoidance and the Chevron deference and arguing that constitutional avoidance should not trump the Chevron deference).

262. 35 U.S.C. $\S 6(c)(2012)$.

263. See supra text accompanying note 226 .

264. Transcript of Oral Argument at 45, Oil States Energy Servs., LLC v. Greene's Energy Grp., 138 S. Ct. 1365 (2018) (No. 16-712).

265. Such an approach where the APJs have final decision-making authority may well raise a different constitutional concern. See Gary Lawson, Appointments and Illegal Adjudication: The AIA Through a Constitutional Lens, 26 GEO. MASON L. REV. (forthcoming 2019), https://ssrn.com/abstract=3105511 [https://perma.cc/7QVJ-A8HL] (last visited Dec. 21, 2018) (arguing that APJs are unconstitutional because they have final decision-making authority-and thus are principal officers under the Constitution - yet have not been appointed by the President with the advice and consent of the Senate). 


\section{Alternative Mechanisms for Increased Agency-Head Control of PTAB Adjudication}

The Director's designation practices raise serious constitutional questions and, at least under Sixth Circuit precedent, would likely be unconstitutional on due process grounds. But even if the constitutional (and constitutional avoidance) arguments ultimately fail, that does not mean the practices are otherwise fair as a matter of administrative justice. As Justice Scalia has famously quipped, "A lot of stuff that's stupid is not unconstitutional." 266 Indeed, in the Article III context, scholars have noted that "the random assignment of federal appellate judges to panels has become a 'hallmark' of the system." 267 If random assignment is a hallmark of Article III adjudication, it is even more important in the agency adjudication context, especially the agency adjudication of private or quasi-private rights or between two private parties. Adjudicators are already not guaranteed Article III's life tenure and salary protections, and the Roberts Court seems interested in formally cabining the powers of non-Article III adjudicators. ${ }^{268}$ In light of these constitutional and fairness concerns, are there other mechanisms the Patent Office could utilize to consistently align PTAB decisions with its policy preferences? This following Subsection explores this question and suggests three main alternatives: (1) granting the Director final decision-making authority; (2) increasing the Patent Office's reliance on rulemaking; and (3) modifying the PTAB's precedential decisions designation process. Part IV.C.4 concludes with an overview of the September 2018 revisions to the PTAB's standard operating procedures to establish new "precedential opinion panel" and precedential-designation processes.

\section{Grant Agency Leadership Final Decision-Making Authority}

Perhaps the most direct route to increase the Director's control over adjudicative outcomes would be to create Director review of PTAB decisions. ${ }^{269}$

266. Jennifer Senior, In Conversation: Antonin Scalia, N.Y. MAG. (Oct. 6, 2013), http://nymag.com/news/features/antonin-scalia-2013-10 [https://perma.cc/4UPN-L253].

267. Emerson H. Tiller \& Frank B. Cross, A Modest Proposal for Improving American Justice, 99 Colum. L. ReV. 215, 216 \& n.4 (1999). But see Adam S. Chilton \& Marin K. Levy, Challenging the Randomness of Panel Assignment in the Federal Courts of Appeals, 101 CORNELL L. REV. 1, 13 (2015) (calling into question the empirical assumption of random assignment).

268. For instance, Chief Justice Roberts, writing for the Court in Stern v. Marshall, 564 U.S. 462, 489 n.6 (2011), significantly limited the reach of Crowell v. Benson, 285 U.S. 22 (1932) and related precedents concerning non-Article III adjudication of private rights. See Stern, 564 U.S. at 506 (Breyer, J., dissenting) ("My disagreement with the majority's conclusion stems in part from my disagreement about the way in which it interprets, or at least emphasizes, certain precedents" concerning non-Article III adjudication.).

269. At that time, the Director was referred to as the Commissioner. The passage of the American Inventors Protection Act of 1999 (AIPA) reorganized the Patent Office and elevated the position of the agency head of the Patent Office from Commissioner to Director. Pub. L. No. 106-113, § 4713, §3(a)(1), 113 Stat. 1501, 1501A-575-I578 (codified as amended at 35 U.S.C. § 3(a)(1) (2012)). This Article does not engage with the larger policy question regarding the ideal structure of the Patent Office. That is, we take as a given that the head of the agency is a single individual who is a political appointee and do not, 
Interestingly, the Director possessed such authority with respect to PTAB's predecessor until 1927, when Congress abolished the right to appeal the adjudicatory board's decision to the Director out of workload concerns. ${ }^{270}$ In lieu of a guaranteed right of appeal to the Director, the 1927 Act created the blueprint for PTAB's rehearing structure and reconstituted the Patent Office's adjudicatory tribunal's membership to include the Director and other highranking officials. ${ }^{271}$ Given the increased popularity of the PTAB, mandated Director review of all PTAB decisions would likely overwhelm the agency head to a greater extent than anticipated in 1927. As a result, the Director's jurisdiction over PTAB appeals should be discretionary. Allowing the Director to review only those cases that she deems necessary to consistently align adjudicative outcomes with her policy preferences would minimize the Director's administrative burden while still allowing her sufficient policy control.

Congress could also consider creating an intermediate appellate board or a judicial office system that may be further subject to discretionary review by the Director (or another high-level political appointee serving in the Director's place). This intermediate level of review before discretionary Director evaluation could lessen demands on the Director by facilitating the identification of cases in which consistency and policy input are most necessary. The Director would also benefit from all cases being summarized and analyzed by two levels of decision-makers, freeing her to focus more on the policy issues and consistency of PTAB decisions. ${ }^{272}$ To further sharpen the Director's involvement in policy or novel legal issues, Congress could require the intermediate appellate board to certify questions to the Director, like it has with the Federal Communications Commission. ${ }^{273}$ This certification process could occur after requiring a public notice and comment period, providing the Director with further input to consider in making the policy or novel legal decision.

Of course, the drawback of granting agency leadership direct review over the PTAB is that it would require congressional action. ${ }^{274}$ While this is likely the most straightforward way to consistently align PTAB decisions with its policy preferences, the rest of this Section considers alternative mechanisms to increase

for example, explore whether the Patent Office should have a commission, board, or body of agency heads.

270. P.J. Federico, Evolution of Patent Office Appeals, 22 J. PAT. OFF. SoC'Y 838, 857 (1940).

271. The 1927 change was technically directed towards patent rejections. In 1939, the internal appeal in interference cases was abolished. Act of Aug. 5, 1939, 53 Stat. 1212.

272. Of course, an additional layer of review would likely increase the costs of challenging a patent at PTAB and may frustrate the agency's ability to complete a trial in one year, as required by the AIA. 35 U.S.C. $§ 316(a)(11)$ (2012). As a result, if Congress creates an additional layer of review, it may want to revisit the one-year time frame for completing a trial.

273. Adjudicatory Re-regulation Proposals, 41 Fed. Reg. 14866 (Apr. 8, 1976). Notably, PTAB regulations allow for a panel or APJ to certify a question of policy to the Chief Administrative Patent Judge. 37 C.F.R. § 41.3(a) (2018).

274. Although the Patent Office created a Precedential Review Panel, see infra Part IV.C.4, which in essence is a type of intermediate appeal board, without Congressional action. 
homogeneity and consistency in PTAB outcomes that would not require an additional statutory grant of authority to the agency.

\section{Increase Reliance on Rulemaking}

One way the Patent Office could help homogenize PTAB decisions is to increase its reliance on rulemaking. Admittedly, the Patent Office's rulemaking authority is relatively circumscribed. Historically, the agency's primary grant of rulemaking authority gave the Patent Office the ability to make rules that "govern the conduct of proceedings in the Office." 275 The Federal Circuit has repeatedly interpreted this grant as primarily enabling the Patent Office to make rules on a variety of procedural matters. ${ }^{276}$ However, the AIA granted the Patent Office additional rulemaking authority with respect to the PTAB proceedings. ${ }^{277}$ The Supreme Court has interpreted this new rulemaking authority to include both procedural and substantive components, although the grant falls short of enabling the agency to promulgate rules on the core patentability standards such as novelty. ${ }^{278}$ Thus, the Patent Office could more fully embrace its rulemaking authority to consistently align PTAB decisions with the agency's policy preferences, although not to the extent of agencies that possess broader substantive rulemaking authority.

Other agencies have followed this path. For instance, the Social Security Administration (SSA), which makes hundreds of thousands of disability determinations each year, has relied heavily on rulemaking to develop policy and guide its ALJs and hearing officers. ${ }^{279}$ Nevertheless, even though the Patent Office may benefit by relying more heavily on rulemaking to announce agency policy, the agency will likely still need some additional review of PTAB determinations to bring homogeneity to its outcomes. For example, while the SSA utilizes rulemaking to cabin ALJ decision-making, the SSA also relies on two other mechanisms to bring uniformity and consistency to ALJs determinations: (1) its Appeals Council, which serves as a review board to ALJs decisions, and (2) Social Security Rulings, in which the agency head designates certain adjudications as precedential. ${ }^{280}$ Moreover, legislative challenges and procedural requirements associated with rulemaking are nontrivial. The costs associated with rulemaking could be so prohibitive that the Patent Office may

275. 35 U.S.C. $\S 2(b)(2)(A)(2012)$.

276. Merck \& Co. v. Kessler, 80 F.3d 1543, 1549-50 (Fed. Cir. 1996).

277. 35 U.S.C. §316(a)(4) (2012) (granting the Patent Office the authority to issue "regulations ... establishing and governing inter partes review under this chapter").

278. Cuozzo Speed Tech. v. Lee, 136 S. Ct. 2131, 2135 (2016) (noting that the agency's new rulemaking authority over PTAB proceedings "is not limited to procedural regulations").

279. Charles H. Koch Jr. \& David A. Koplow, The Fourth Bite at the Apple: A Study of the Operation and Utility of the Social Security Administration's Appeals Council, 17 FLA. ST. U. L. REV. 199, 267-68 (1990).

280. Id. 
not be able to rely solely on rulemaking to consistently align PTAB outcomes with the agency's policy preferences. ${ }^{281}$

Finally, it is important to acknowledge that the Supreme Court has made clear that an agency's choice of policy-making mechanism falls within the ambit of the agency's discretion. The Court has noted that there is "a very definite place for the case-by-case evolution of statutory standards," 282 and "the choice made between proceeding by general rule or by individual, ad hoc litigation is one that lies primarily in the informed discretion of the administrative agency."283 Besides financial considerations, there are a number of reasons why the Patent Office may want to proceed with adjudication rather than legislative rule. In particular, the agency may need to act quickly to clarify the law, and rulemaking may be too time consuming. ${ }^{284}$ Thus, although it would likely benefit from increasing its reliance on legislative rules, the Patent Office may have legitimate reasons to rely on outside mechanisms to bring homogeneity to PTAB determinations.

\section{Modify the PTAB Precedential Decisions Designation Process}

How could the Director of the Patent Office ensure that adjudicative outcomes consistently follow agency policy preferences without solely relying on rulemaking authority? One promising alternative is the increasing designation of PTAB determinations as precedential. This pathway would likely require the Patent Office to modify the process by which PTAB decisions are designated precedential to give the Director or the Chief Administrative Patent Judge (CAPJ) greater control over this determination. Because precedential opinions are binding in all future cases before the PTAB until they are superseded by later binding authority, the Director could use the precedential-designation process to better align PTAB outcomes with the agency's policy preferences. Indeed, as discussed in Part IV.C.4, the PTAB recently amended its standard operating procedures to streamline the precedent-designation process.

Since the new adjudicative procedures have come to fruition, the PTAB has issued over fifteen hundred written decisions, but only thirteen have been designated precedential. ${ }^{285}$ This seems like an alarmingly low number given the

281. See, e.g., Jerry L. MASHAW, Richard A. MERrill \& PETER M. SHANe, AdMinistrative LAW: THE AMERICAN PUBLIC LAW SYSTEM CASES AND MATERIALS 617-20 (6th ed. 2009) (describing institutional impediments to rulemaking).

282. SEC v. Chenery Corp., 332 U.S. 194, 203 (1947).

283. Id.

284. See, e.g., Magill, supra note 9, at 1396-97 (exploring factors that influence whether an agency chooses adjudication or rulemaking to make policy); see also Aaron Nielson, Beyond Seminole Rock, 105 GEO. L.J. 943, 972-82 (2017) (arguing against adjudication as a substitute to rulemaking or agency policy-making).

285. U.S. Patent \& TRAdemark Office, PATENT TRial and ApPeal BoArd Statistics (2017), https://www.uspto.gov/sites/default/files/documents/AIA Statistics_March2017.pdf [https://perma.cc/ET4J-LC5Q] (last visited Dec. 22, 2018); List of Precedential Decisions of the Patent Trial and Appeal Board, USPTO, https://www.uspto.gov/patents-application-process/appealing-patent- 
number of novel legal questions the PTAB has faced since the passage of the AIA. The lack of precedential decisions is likely due, at least in part, to the Patent Office's cumbersome process for designating an opinion as precedential-a process that seems to be an artifact of when the Patent Office's adjudicatory tribunal constituted much smaller membership.

Prior to the September 2018 revisions to the PTAB standard operation procedures, the process began with a nomination of an opinion, which could occur by any member of the PTAB (including the Director), interested party, or member of the public. ${ }^{286}$ The CAPJ received the nominations and each PTAB member could vote and comment in writing as to whether the opinion should be designated as precedential. ${ }^{287}$ Only those PTAB opinions that received approval from the CAPJ, the Director, and the majority of APJs would be designated as precedential. Because no opinion could be designated as precedential without the Director's consent, she had veto authority. ${ }^{288}$

However, under the old guidelines the Director could not designate an opinion precedential without the consensus of the CAPJ and the majority of APJs (which is now close to three hundred). This cumbersome process greatly limited the Director's ability to consistently align PTAB outcomes with the agency's policy preferences.

An agency-wide survey of precedential designation procedures suggests there is wide variety in this area in the administrative state, but it also provides evidence that agencies with a high volume of adjudications more unilaterally rely on agency leadership to make precedential determinations. For instance, some adjudicative bodies, such as the National Labor Relations Board and the Environmental Appeal Board, do not provide any designation for their decisions. ${ }^{289}$ Other agencies, like the Patent Office, designate decisions as precedential and typically utilize a process that includes a majority vote by board members. However, these adjudicative bodies generally comprise substantially fewer members than the PTAB. Take, for example, the Board of Immigration Appeals (BIA), which has seventeen members. ${ }^{290}$ The BIA, like the Patent

decisions/decisions-and-opinions/precedential [https://perma.cc/62LP-LUVS] (last visited Dec. 22, 2018) (citing thirteen trial opinions, which excludes ex parte patent denials and most opinions issued before 2011).

286. Patent Trial and ApPeal BD., Standard Operating Procedure 2 (Revision 9): PUBLICATION OF OPINIONS AND DESIGNATION OF OPINIONS AS PRECEDENTIAL, INFORMATIVE, AND ROUTINE (2014), https://www.uspto.gov/sites/default/files/documents/sop2-revision-9-dated-9-222014.pdf [https://perma.cc/UG6Q-3DQU]. The public or any interested party had to nominate an opinion for precedential status within sixty days of the opinion's issuance. Id. at 2.

287. Id.

288. Id.

289. See Cases and Decisions, NAT'L LABOR RESOURCES BD., https://www.nlrb.gov/casesdecisions [https://perma.cc/Q59S-EV7E] (last visited Dec. 22, 2018); EAB Decisions, U.S. ENVTL. PROT. AGENCY, https://yosemite.epa.gov/oa/EAB_Web_Docket.nsf/Board+Decisions?OpenPage [https://perma.cc/JH5W-UZS8] (last visited Dec. 22, 2018).

290. See supra note 173 and accompanying text. 
Office, requires a majority-vote of permanent board members to designate an opinion as precedential. ${ }^{291}$ Moreover, unlike the Patent Office, the Attorney General can review BIA decisions directly. Thus, there is arguably less need to utilize precedential designation to control BIA decision-making. ${ }^{292}$

Perhaps most instructive are the designation practices of other agencies that adjudicate a high volume of cases. Here again, the Social Security Administration is illustrative. While the Patent Office comprises an initial decision made by a patent examiner, followed by review by the PTAB, the SSA comprises three stages of intra-agency review: the initial determination by a hearing officer, an appeal to an ALJ, and a subsequent appeal of the ALJ's decision to the Appellate Council. ${ }^{293}$ Unlike the PTAB, the Appellate Council does not designate its opinions as precedential (or any other status). Instead, the SSA has adopted a practice of issuing Social Security Rulings, which designate adjudications at any level as precedential and internally binding on all components of the SSA. ${ }^{294}$ These Social Security Rulings in effect provide the SSA Commissioner with the ability to designate Appellate Council and ALJ decisions as precedential unilaterally. ${ }^{295}$

Finally, the Patent Act appears to grant the Director legal authority to independently make precedential determinations. Even though the Act itself is silent both on whether PTAB decisions should carry different designations and on the process that should govern such a determination, the Patent Act provides that "[t]he Director shall be responsible for providing policy direction and management supervision for the Office and for the issuance of patents." 296 This language and broad statutory authority to promulgate rules that govern PTAB adjudication seem more than sufficient to empower the Director to modify the existing procedure on designating PTAB decisions, including shifting more control to agency leadership.

291. 8. C.F.R. § 1003.1(g) (2018) ("By majority vote of the permanent Board members, selected decisions of the Board rendered by a three-member panel or by the Board en banc may be designated to serve as precedents in all proceedings involving the same issue or issues.").

292. See id. § 1003.1(h).

293. Koch \& Koplow, supra note 279, at 219-24.

294. 20 C.F.R. $\S 402.35(b)(1)$ (2018) ("We publish Social Security Rulings in the FEDERAL REGISTER under the authority of the Commissioner of Social Security. They are binding on all components of the Social Security Administration. These rulings represent precedent final opinions and orders and statements of policy and interpretations that we have adopted."). There has been some controversy as to whether these rulings bind SAA ALJs. See Koch \& Koplow, supra note 279, at 23233.

295. Preface to Rulings: Social Security Rulings and Acquiescence Rulings, SOCIAL SECURITY ADMIN., https://www.ssa.gov/OP_Home/rulings/rulings-pref.html [https://perma.cc/268G-T887] (last visited Dec. 22, 2018).

296. 35 U.S.C. $\S 3(a)(2)(A)(2012)$. 


\section{Post-Script: Assessing the PTAB's New "Precedential Opinion Panel" and Precedential-Designation Processes}

No doubt motivated by the concerns addressed in this Section, ${ }^{297}$ in September 2018, the PTAB substantially revised its standard operating procedures to set out two separate, but streamlined pathways in which PTAB opinions may be designated as precedential. These new procedures adopt some variant of our first and third recommendations regarding greater leadership control of final PTAB decision-making and an easier means for the PTAB to designate opinions as precedential. ${ }^{298}$

First, the new procedures modify the prior process discussed in Part IV.C.3 in which opinions are nominated and designated as precedential to afford the Director near unilateral authority in the designation decision. The procedures state that the Director retains sole discretion to designate an opinion precedential, but establishes an Executive Judges Committee, comprising the PTAB Chief Judge, Deputy Chief Judge, and the Operational Vice Chief Judges, to advise the Director in this role. ${ }^{299}$ Similar to the prior procedure, any member of the public, interested party, or PTAB member may nominate a decision for precedential consideration. ${ }^{300}$ The Executive Judges Committee will evaluate and vote on whether to recommend designating the nominated decision as precedential. ${ }^{301}$ If the Director accepts the committee's recommendation, the designation decision will be published following the public notice and comment. ${ }^{302}$ Importantly, the majority vote by APJs is no longer a necessary condition for precedential status, which greatly consolidates the power of the Director to designate decisions as precedential. The new procedures also provide a similar process for dedesignating a precedential decision that the Director deems should no longer carry that designation. ${ }^{303}$

Second, these revisions establish a new Precedential Opinion Panel, composed of the Director, the Commissioner for Patents, and the Chief Administrative Patent Judge, which rehears issues in PTAB trials. ${ }^{304}$ Similar to the modified procedure for designating opinions as precedential above, the Director has sole discretion to designate Precedential Opinion Panel opinions as

297. A draft of this Article was first made public on the Social Science Research Network on March 8, 2018. These developments at the Patent Office did not emerge until near the end of the editing process. We appreciate the California Law Review's flexibility in allowing us to add this post-script to react to these new standard operating procedures.

298. See U.S. PAtent \& TRAdemark Office, Revisions to Standard Operating Procedures: Paneling and Precedential Decisions (Sept. 20, 2018), https://www.uspto.gov/patents-applicationprocess/patent-trial-and-appeal-board/procedures/revisions-standard-operating [https://perma.cc/3WKH-VKWC].

299. Id. at 4

300. Id. at 9 .

301. Id. at 10

302. Id. at 11 (citing 37 C.F.R. § 1.14).

303. Id. at 12 .

304. Id. at 4 . 
precedential $^{305}$ According to the new procedures, the Precedential Opinion Panel is "to establish binding agency authority concerning major policy or procedural issues ... in the limited situations where it is appropriate to create such binding agency authority through adjudication before the Board." 306 The procedures indicate it may be appropriate to create binding agency authority "to resolve conflicts between Board decisions [or] to promote certainty and consistency ... ." ${ }^{\prime 307}$ Such Precedential Opinion Panel review is discretionary and unreviewable. ${ }^{308}$ The Director may convene the panel in a given case sua sponte, or any party or any other PTAB member may request such review. ${ }^{309}$ To assist the Director in considering review requests raised by parties or other PTAB members, the new procedures establish a screening committee that makes recommendations to the Director. ${ }^{310}$ If the Director decides to grant such review, the parties will be notified and may be given an opportunity to provide additional briefing. ${ }^{311}$

The Precedential Opinion Panel in essence replaces the Director's prior panel-stacking practice with a new rehearing process that arguably avoids the constitutional concerns of the prior practice while still achieving its objectives of greater agency-head control. Moreover, having a three-member board deciding precedent instead of a majority vote among the entire PTAB membership should simplify the precedent-making process. Streamlining the designation process to enable agency leadership to make this determination more unilaterally should result in increased reliance on precedential designations, improving the alignment of the PTAB's decisions with the agency's policy preferences. Other agencies, especially those that make high volume adjudicative decisions, already enable agency leadership to unilaterally make precedential determinations. In addition, it seems clear that the Patent Act grants the Director the ability to do so. Finally, unlike the old procedure by which the Director can select like-minded APJs to serve on panels, this new process by which PTAB decisions are designated precedential does not raise as serious due process or fairness concerns. ${ }^{312}$

\footnotetext{
305. Id. at 8 .

306. Id. at 3 .

307. Id. at 4 .

308. Id. at 6 .

309. See id. at 5-6.

310. See id. at 6-7.

311. Id. at 7.

312. Stuart Benjamin and Arti Rai have argued that precedential PTAB decisions are most worthy of Chevron deference. See Benjamin \& Rai, supra note 198, at 1584-87; accord Christopher J. Walker, Chevron Deference and Patent Exceptionalism, 65 DUKE L.J. ONLINE 149, 153 (2016). On one hand, having the Director be the sole determiner of precedential status could enhance an argument that legal interpretations of ambiguous terms of the Patent Act announced during PTAB proceedings should warrant Chevron deference. To the extent that the PTAB must speak for the agency-that is, the Director - shifting power to agency leadership on the precedential determination further enhances a Chevron deference argument. On the other hand, removing APJs from the decision-making process of precedential status could cut against an argument for strong deference. To the extent that a Chevron
} 
In sum, although the Director still lacks unilateral final decision-making authority over PTAB decisions, these revisions to the PTAB's standard operating procedures address many of the concerns discussed in this Section. The Precedential Opinion Panel review process should allow the Director to exert more control over PTAB adjudicative outcomes, and the new precedentialdesignation process should empower the Director to better shape policy-making and consistency in PTAB adjudication. It will be interesting to see how these processes shape agency adjudication at the Patent Office in the years to come.

\section{CONCLUSION}

When the Supreme Court heard oral argument in the constitutional challenge to the PTAB last year, various Justices raised concerns about this novel agency tribunal, including concerns about how the Patent Office Director had attempted to overcome her lack of final decision-making authority by stacking panels on rehearing with APJs who share her substantive inclinations. ${ }^{313}$ Attempting to address those concerns, the Deputy Solicitor General referred to the Patent Office Director as the "chief judge." This flummoxed Chief Justice Roberts. He noted that "[w]hen we say 'judge,' we usually mean something else": an Article III federal judge, not an "executive employee." 314 Justice Kagan came to the rescue with a seemingly friendly clarifying question: "There are administrative law judges all over this country, aren't there?"315

Justice Kagan's reference to ALJs reflects the lost world of agency adjudication - the formal adjudication set forth in the APA that Justice Kagan no doubt taught in her administrative law classes. Today, however, most formallike agency adjudication occurs outside of the APA - not before ALJs but a variety of other administrative judges, hearing officers, and other agency personnel. PTAB adjudication is one such example. Within this new world of agency adjudication, PTAB adjudication is not that unusual. But it lacks one critical feature that exists in both the lost and new world of agency adjudication: agency-head final decision-making authority. As we argue in this Article, this deficit at the Patent Office can and should be addressed by internal agency practices, agency rulemaking, or even statutory amendment.

Failure to bring PTAB adjudication within the mainstream of agency adjudication could prove problematic for the future of patent adjudication within the Patent Office. Indeed, if Gary Lawson is correct, the Director's lack of final decision-making authority could raise a separate constitutional problem. Under

inquiry considers the procedural protections that lead to good decision-making - that is, formal adjudication and rulemaking often warrant Chevron deference for this reason-then removing APJs from precedential determination could weaken an argument that legal interpretations of ambiguous terms of the Patent Act announced in precedential PTAB decisions merit strong deference.

313. Transcript of Oral Argument at 45-47, Oil States Energy Servs., LLC v. Greene's Energy Grp., 138 S. Ct. 1365 (2018) (No. 16-712).

314. Id. at 46.

315. Id. 
the current statutory and regulatory scheme, the APJs, not the Senate-confirmed Patent Office Director, have final decision-making authority (though the September 2018 revisions to the PTAB operating procedures provide for greater agency-head control and thus mitigate concerns against this separate constitutional problem). Therefore, Lawson argues, APJs are principal officers for purposes of the Appointments Clause and must be appointed by the President with advice and consent of the Senate. ${ }^{316}$

In all events, the importance of agency-head final decision-making authority certainly merits further theoretical development and empirical investigation. This Article hopefully motivates further inquiry and, in the process, demonstrates how the new world of agency adjudication differs from the lost world contemplated by the Congress that enacted the APA over seven decades ago.

316. Lawson, Appointments and Illegal Adjudication, supra note 265, at 6. 
[Vol. 107:141 